OPEN ACCESS

Edited by:

Francesco Miceli,

University of Naples Federico II, Italy

Reviewed by:

Vincenzo Calderone,

University of Pisa, Italy

Nikita Gamper,

University of Leeds, United Kingdom

*Correspondence:

lain A. Greenwood

grenwood@sgul.ac.uk

Samuel N. Baldwin

m1405629@sgul.ac.uk

Specialty section: This article was submitted to

Membrane Physiology

and Membrane Biophysics,

a section of the journal

Frontiers in Physiology

Received: 25 August 2020 Accepted: 13 November 2020

Published: 07 December 2020

Citation:

Baldwin SN, Sandow SL, Mondéjar-Parreño G, Stott JB and Greenwood IA (2020) $K_{V} 7$ Channel Expression and Function Within Rat

Mesenteric Endothelial Cells.

Front. Physiol. 11:598779.

doi: 10.3389/fphys.2020.598779

\section{Kv7 Channel Expression and Function Within Rat Mesenteric Endothelial Cells}

\author{
Samuel N. Baldwin ${ }^{1 *}$, Shaun L. Sandow ${ }^{2}$, Gema Mondéjar-Parreño ${ }^{3}$, Jennifer B. Stott ${ }^{1}$ \\ and lain A. Greenwood ${ }^{1 *}$
}

' Vascular Biology Research Centre, Institute of Molecular and Clinical Sciences, St George's University of London, London, United Kingdom, ${ }^{2}$ Biomedical Science, School of Health and Sports Science, University of the Sunshine Coast, Maroochydore, QLD, Australia, ${ }^{3}$ Department of Pharmacology and Toxicology, School of Medicine, Complutense University of Madrid, Madrid, Spain

Background and Purpose: Arterial diameter is dictated by the contractile state of the vascular smooth muscle cells (VSMCs), which is modulated by direct and indirect inputs from endothelial cells (ECs). Modulators of KCNQ-encoded $\mathrm{kV}_{\mathrm{V}} 7$ channels have considerable impact on arterial diameter and these channels are known to be expressed in VSMCs but not yet defined in ECs. However, expression of kv7 channels in ECs would add an extra level of vascular control. This study aims to characterize the expression and function of $\mathrm{K}_{V} 7$ channels within rat mesenteric artery ECs.

Experimental Approach: In rat mesenteric artery, $\mathrm{KCNQ}$ transcript and $\mathrm{K}_{\mathrm{V}} 7$ channel protein expression were determined via RT-qPCR, immunocytochemistry, immunohistochemistry and immunoelectron microscopy. Wire myography was used to determine vascular reactivity.

Key Results: KCNQ transcript was identified in isolated ECs and VSMCs. $\mathrm{K}_{V} 7.1, \mathrm{~K}_{\mathrm{V}} 7.4$ and $K_{V} 7.5$ protein expression was determined in both isolated EC and VSMC and in whole vessels. Removal of ECs attenuated vasorelaxation to two structurally different $\mathrm{K}_{\mathrm{V}} 7.2-5$ activators S-1 and ML213. $\mathrm{K}_{\mathrm{R}} 2$ blockers $\mathrm{ML} 133$, and $\mathrm{BaCl}_{2}$ also attenuated S-1 or ML213-mediated vasorelaxation in an endothelium-dependent process. $\mathrm{K}_{V} 7$ inhibition attenuated receptor-dependent nitric oxide (NO)-mediated vasorelaxation to carbachol, but had no impact on relaxation to the NO donor, SNP.

Conclusion and Implications: In rat mesenteric artery ECs, $\mathrm{K}_{\mathrm{V}} 7.4$ and $\mathrm{K}_{\mathrm{V}} 7.5$ channels are expressed, functionally interact with endothelial $K_{\mathbb{R}} 2 . x$ channels and contribute to endogenous eNOS-mediated relaxation. This study identifies $K_{V} 7$ channels as novel functional channels within rat mesenteric ECs and suggests that these channels are involved in NO release from the endothelium of these vessels.

Keywords: pharmacology, vascular biology, endothelial cell, $\mathrm{K}_{\mathrm{V}} 7$ channel, $\mathrm{K}_{\mathrm{IR}}$ channel, carbachol 


\section{INTRODUCTION}

KCNQ-encoded $\mathrm{K}_{V} 7$ channels are key regulators of arterial reactivity. Within the vasculature, of the five KCNQ subtypes, KCNQ4 is predominantly expressed, followed by KCNQ5 > KCNQ1; with little to no contribution from KCNQ2/3 (Ohya et al., 2003; Yeung et al., 2007; Ng et al., 2011). In human and rodent blood vessels $\mathrm{K}_{\mathrm{V}} 7$ channels contribute to resting tone (Ohya et al., 2003; Yeung et al., 2007; Mackie et al., 2008; Ng et al., 2011), whereby their blockers such as linopirdine or XE991 produce contractions or enhance vasoconstrictor responses. In addition, a range of $\mathrm{K}_{\mathrm{V}} 7$ channel activators including retigabine, S-1 and ML213 are effective relaxants of pre-contracted arterial tone. Furthermore, $\mathrm{K}_{\mathrm{V}} 7$ channels also represent functional end targets for a myriad of endogenous vasoactive responses, wherein channel activity is impaired during PKC-mediated vasoconstriction (Brueggemann et al., 2006) and enhanced as a result of cGMP and cAMP dependent receptor-mediated vasodilation (e.g., Chadha et al., 2012; Khanamiri et al., 2013; Stott et al., 2014, 2015; Mani et al., 2016; Brueggemann et al., 2018; Mondéjar-Parreño et al., 2019). To date, vascular $\mathrm{K}_{\mathrm{V}} 7$ channel studies have focused predominantly on vascular smooth muscle cells (VSMCs) or whole arteries, and as a result it is currently unclear whether endothelial cells (ECs) express $\mathrm{K}_{\mathrm{V}} 7$ channels and if so, what their functional role may be.

Endothelial cells form the inner layer of blood vessels and constitute a paracrine signaling platform which regulates VSMC contractility, vascular resistance and ultimately blood flow through the release of nitric oxide (NO), prostacyclin, epoxyeicosatrienoic acid and others; including the generation and spread of endothelium-derived hyperpolarization (EDH) (McGuire et al., 2001). Myoendothelial (ME) projections within fenestrations (holes) of the internal elastic lamina (IEL) facilitate the presence gap junctions (MEGJs) at a proportion of such sites $(\sim 50 \%$ in adult rat 1 st-3rd order 'large' mesenteric arteries; MA; Sandow et al., 2009) which permits heterocellular electrochemical coupling via connexin proteins (Sandow et al., 2012). These sites enable the transfer of EC-derived signals via the flow of both small molecules $<\sim 1 \mathrm{kDa}$ and current between the cells. In endothelium-dependent relaxation of rat MA, a fundamental role for small/intermediate conductance calciumactivated potassium $\left(\mathrm{SK}_{\mathrm{Ca}}\right.$ and $\mathrm{IK}_{\mathrm{Ca}}$, respectively; Sandow

Abbreviations: 4-AP, 4-aminopyridine; Acta2, $\alpha$-smooth muscle actin-2; $\mathrm{CCh}$, carbachol; cGMP, cyclic guanosine monophosphate; $\mathrm{Cq}$, quantification cycle; $\mathrm{CYC1}$, cytochrome $\mathrm{Cl}$; EC, endothelial cell; $\mathrm{EDH}$, endothelium derived hyperpolarization; GAPD, glyceraldehyde-3-phosphate dehydrogenase; eNOS, endothelial nitric oxide synthase; $\mathrm{IK}_{\mathrm{Ca}}$, intermediate conductance calciumactivated potassium channel; IEL, internal elastic lamina; $\mathrm{K}_{\mathrm{IR}}$, inwardly rectifying potassium channel; $\mathrm{K}_{\mathrm{V}}$, voltage-gated potassium channel; L-NAME, L-nitroarginine methyl ester; MA, mesenteric artery; MO, methoxamine; Myh11, myosin heavy chain 11; NO, nitric oxide; PECAM-1, platelet endothelial cell adhesion molecule-1; RT-qPCR, reverse-transcription quantitative polymerase chain reaction; SEM, standard error of the mean; $\mathrm{SK}_{\mathrm{Ca}}$, small conductance calcium-activated potassium channel; SNP, S-nitroprusside; TEA, tetraethylammonium; VSMC, vascular smooth muscle cell; vWBF, von-Willebrand factor. et al., 2006; Dora et al., 2008), transient receptor potential canonical type 3 (Senadheera et al., 2012), inwardly rectifying potassium channels ( $\left.\mathrm{K}_{\mathrm{IR}} 2\right)$ (Goto et al., 2004), as well as inositol-1,3,4 trisphosphate receptor/s (Fukao et al., 1997) has been demonstrated.

Identification of $\mathrm{K}_{\mathrm{V}} 7$ expression in ECs would open up a new layer of vascular control by these channels and is a necessary requisite for understanding the role of these channels in vascular health and disease. This study aims to ascertain whether rat mesenteric ECs express $\mathrm{K}_{\mathrm{V}} 7$ channels, and if so, what their functional implications may be. This study shows that $\mathrm{K}_{V} 7$ channels are expressed in rat mesenteric artery ECs and contribute to both $\mathrm{K}_{\mathrm{V}} 7$ activator-mediated relaxation via a potential functional interaction with $\mathrm{K}_{\mathrm{IR}} 2$ channels and endothelial NO synthase (eNOS)-dependent axis of carbachol (CCh)-mediated vasorelaxation.

\section{MATERIALS AND METHODS}

\section{Animal Models}

Experiments were performed on MA from Male Wistar rats (Charles River, Margate, United Kingdom) ages 11-14 weeks (200-350 g) from the Biological Research Facility, St George's, London, United Kingdom; and from the Animal Resources Center, Perth, Australia. Animals were housed in cages with free access to water and food (RM1; Dietex Inter-national, United Kingdom) ad libitum, with a 12-h light/dark cycle and constant temperature and humidity $\left(21 \pm 1{ }^{\circ} \mathrm{C} ; 50 \% \pm 10 \%\right.$ humidity) in accordance with the Animal (Scientific Procedures) Act 1986, the guidelines of the National Health and Medical Research Council of Australia and the UNSW Animal Ethics and Experimentation Committee (AEEC \#18/86B). Animals were kept in LSB Aspen woodchip bedding. Animals were culled by either cervical dislocation with secondary confirmation via cessation of the circulation by femoral artery severance or were anesthetized with sodium pentathol (intraperitoneal, $100 \mathrm{mg} / \mathrm{kg}$ ) in accordance with Schedule 1 of the ASPA 1986.

Either whole mesenteric plexus or $2 \mathrm{nd} / 3 \mathrm{rd} / 4$ th order MA were used with vessel order identified from the second bifurcation of the superior MA. Arteries were dissected, cleaned of fat and adherent tissue and stored on ice within physiological salt solution (PSS) of the following composition $\left(\mathrm{mmol}^{-1} \mathrm{~L}^{-1}\right) ; 119$ $\mathrm{NaCl}, 4.5 \mathrm{KCl}, 1.17 \mathrm{MgSO}_{4} .7 \mathrm{H}_{2} 0,1.18 \mathrm{NaH}_{2} \mathrm{PO}_{4}, 25 \mathrm{NaHCO}_{3}$, 5 glucose, $1.25 \mathrm{CaCl}_{2}$.

\section{Reverse Transcription Quantitative Polymerase Chain Reaction}

Second and third order MA segments were enzymatically digested to obtain either freshly isolated ECs (as previous, Greenberg et al., 2016) or VSMCs. Briefly, vessels were washed in Hanks' Balanced Salt Solution (HBSS; ThermoFisher Scientific, GIBCO, 14170-088) containing $50 \mu \mathrm{mol}-\mathrm{L}^{-1} \mathrm{CaCl}_{2}$ for $5 \mathrm{~min}$ at $37^{\circ} \mathrm{C}$, the media was then replaced in HBSS containing $50 \mu \mathrm{mol}-$ $\mathrm{L}^{-1} \mathrm{CaCl}_{2}$ with $1 \mathrm{mg} / \mathrm{mL}$ collagenase IA (Sigma Aldrich, C9891, United Kingdom) for $15 \mathrm{~min}$ at $37^{\circ} \mathrm{C}$. Vessels were washed 
in HBSS containing $50 \mu \mathrm{mol}-\mathrm{L}^{-1} \mathrm{CaCl}_{2}$ for $10 \mathrm{~min}$ at $37^{\circ} \mathrm{C}$. The supernatant was removed and the vessels suspended in fresh HBSS containing $75 \mu \mathrm{mol}-\mathrm{L}^{-1} \mathrm{CaCl}_{2}$. For RT-qPCR, ECs were dissociated using a wide-bore smooth-tipped pipette and identified under the microscope (x10) as sheets of cells independent from the vessel which were harvested and stored separately from the residual VSMCs.

mRNA from both isolated ECs and VSMCs was extracted using Monarch Total RNA Miniprep Kit (New England BioLabs, Ipswich, MA, United States) and reverse transcribed via LunaScript RT SuperMix Kit (New England BioLabs, Ipswich, MA, United States). Quantitative analysis of relative gene expression was assessed via CFX-96 Real-Time PCR Detection System (BioRad, Hertfordshire, United Kingdom). Samples were run in duplicate to account for variation. Samples were run in BrightWhite qPCR plate (Primer Design, Camberley, United Kingdom), with each well containing $20 \mu \mathrm{L}$ of reaction solution containing: $10 \mu \mathrm{L}$ of PrecisionPLUS qPCR Master Mix (Primer Design, Camberley, United Kingdom), $300 \mathrm{nmol}^{-1} \mathrm{~L}^{-1}$ of gene specific target primer (Thermofisher scientific, Waltham, MA, United States) and $10 \mathrm{ng}$ of cDNA sample made up to $20 \mu \mathrm{L}$ total volume with nuclease free water. Run protocol: (1) activation step (15 min:95 $\left.{ }^{\circ} \mathrm{C}\right)$, (2) denaturation step $\left(15 \mathrm{~s}: 94^{\circ} \mathrm{C}\right)$, (3) annealing step (30 s: $55^{\circ} \mathrm{C}$ ), and (4) extension step $\left(30 \mathrm{~s}\right.$ : $\left.70^{\circ} \mathrm{C}\right)$. Steps $2-4$ were repeated x 40. Quantification cycle $(\mathrm{Cq})$ was determined via Bio-Rad CFX96 Manager 3.0. Cq values were normalised to housekeeper genes expressed as a $2^{-\Delta \mathrm{Cq}}$ when compared to appropriate reference genes including 14-3-3 Zeta (YWHAZ) and glyceraldehyde-3-phosphate dehydrogenase (GAPD). Cell isolation for VSMCs and ECs was validated by either positive expression of VSMC specific marker $\alpha$-actin 2 (Acta2) or EC specific marker-platelet endothelial cell adhesion molecule-1 (Pecam-1) respectively. See Table 1 for a list of the primers used in the following (Jepps et al., 2011; Askew Page et al., 2019; ThermoFisher Scientific).

\begin{tabular}{|c|c|c|c|}
\hline Gene & $\begin{array}{l}\text { (+) Forward primer sequence } \\
\text { (-) Reverse primer sequence }\end{array}$ & $\begin{array}{l}\text { Gene accession } \\
\text { number }\end{array}$ & $\begin{array}{l}\text { Amplicon } \\
\text { (bp) }\end{array}$ \\
\hline Acta2 & $\begin{array}{l}\text { ATCCGATAGAACACGGCATC } \\
\text { AGGCATAGAGGGACAGCACA }\end{array}$ & NM_031004.2 & 228 \\
\hline Pecam1 & $\begin{array}{l}\text { CTCCTAAGAGCAAAGAGCAACTTC } \\
\text { TACACTGGTATTCCATGTCTCTGG }\end{array}$ & NM_031591.1 & 100 \\
\hline Kcnq1 & $\begin{array}{l}\text { TGGGTCTCATCTTCTCCTCC } \\
\text { GTAGCCAATGGTGGTGACTG }\end{array}$ & NM_032073 & 124 \\
\hline Kcnq2 & $\begin{array}{l}\text { AAGAGCAGCATCGGCAAAAA } \\
\text { GGTGCGTGAGAGGTTAGTAGCA- }\end{array}$ & NM_133322 & 101 \\
\hline Kcnq3 & $\begin{array}{l}\text { CAGCAAAGAACTCATCACCG } \\
\text { ATGGTGGCCAGTGTGATCAG }\end{array}$ & AF091247 & 161 \\
\hline Kcnq4 & $\begin{array}{l}\text { GAATGAGCAGCTCCCAGAAG } \\
\text { AAGCTCCAGCTITCTGCAC }\end{array}$ & XM_233477.8 & 133 \\
\hline Kcnq5 & $\begin{array}{l}\text { AACTGATGAGGAGGTCGGTG } \\
\text { GATGACCGTGACCTCCAGT }\end{array}$ & XM_001071249.3 & 120 \\
\hline
\end{tabular}

\section{Immunocytochemistry}

Freshly dispersed ECs (as above), together with residual VSMCs were left for $1 \mathrm{hr}$ before use. Cells were then fixed in $4 \%$ paraformaldehyde (Sigma-Aldrich, United Kingdom) in PBS for $20 \mathrm{~min}$ at RT as previously described (Barrese et al., 2018a). Cells were treated with $0.1 \mathrm{~mol}-\mathrm{L}^{-1}$ glycine for $5 \mathrm{~min}$ and incubated for $1 \mathrm{~h}$ with blocking solution (PBS-0.1\% Triton X-100-10\% bovine serum albumin) at RT. Following incubation overnight at $4^{\circ} \mathrm{C}$ with primary antibodies (Table 2) diluted in blocking solution (anti-PECAM-1 for ECs, anti- $\alpha$-actin for VSMCs and anti-KV7.1, $K_{V} 7.4$, and $K_{V} 7.5$ channel for ECs/VSMCs), cells were then washed for $20 \mathrm{~min}$ with PBS, incubated for $1 \mathrm{~h}$ at RT with the secondary conjugated antibodies diluted in blocking solution. Excess secondary antibody was removed by washing with PBS and cells mounted using media containing $4^{\prime}, 6-$ diamidino-2-phenylindole (DAPI) for nuclear counterstaining. Using triple staining, ECs and VSMC were differentiated via the following: ECs were positive for anti PECAM-1 and negative for anti- $\alpha$-actin; while VSMC was positive for anti- $\alpha$-actin and negative for anti-PECAM-1 (data not shown). Cells were analyzed using a Zeiss LSM 510 Meta argon/krypton laser scanning confocal microscope (Image Resource Facility, St George's University, London).

\section{Cell Culture}

Chinese Hamster Ovary (CHO) cells were maintained in DMEM supplemented with $10 \%$ fetal bovine serum, $2 \mathrm{mmol}^{-\mathrm{L}^{-1}} \mathrm{~L}$ glutamine, and $1 \%$ penicillin/streptomycin (Sigma Aldrich, Dorset, United Kingdom) and maintained at $37^{\circ} \mathrm{C}$ with $5 \%$ $\mathrm{CO}_{2}$ in an incubator. Cells were plated in a 24-well plate, incubated for $24 \mathrm{hr}$ then transfected with either $\mathrm{K}_{\mathrm{V}} 7.1, \mathrm{~K}_{\mathrm{V}} 7.4$ or $K_{V} 7.5$ plasmids using Lipofecamine 2000 (Thermofisher, Paisley, United Kingdom) as described previously (Barrese et al., 2018a). After $24 \mathrm{~h}$, cells were fixed and stained as described above.

\section{Immunohistochemistry}

Animals were anesthetized with sodium pentathol (intraperitoneal, $100 \mathrm{mg} / \mathrm{kg}$ ) and perfusion fixed (Sandow et al., 2004) in $2 \%$ paraformaldehyde in 0.1 mol- $\mathrm{L}^{-1}$ PBS. Third to 4th order MA segments were dissected, opened laterally and pinned as a sheet to a Sylgard dish. Segments were washed in PBS $(3 \times 5 \mathrm{~min})$, incubated in blocking buffer (PBS with $1 \%$ BSA and $0.2 \%$ Triton) at room temperature (RT) for $2 \mathrm{~h}$ and then overnight with primary antibody (Table 2) in blocking buffer at $4^{\circ} \mathrm{C}$, washed again $(3 \times 5 \mathrm{~min}$ with gentle agitation), and incubated in secondary antibody (Table 2; matched to the respective primary) in PBS with $0.1 \%$ Triton in PBS for $2 \mathrm{~h}$ at RT. Tissue was mounted on slides in anti-fade media containing propidium iodide (PI) or DAPI (Table 2) and imaged with uniform confocal settings. Incubation of tissue with secondary only was used as a 'zero' setting for confocal imaging. Controls involved substitution of primary with isotype control, with concentration (where provided by manufacturer) matched, or 10 -fold higher than the respective antibody of interest (Table 2). Working Ab dilutions were prepared in accordance with previous work (Jepps et al., 2009; Chadha et al., 2012). Confocal image 
TABLE 2 | Immunocyto/histochemistry reagents and use (Jepps et al., 2009; Chadha et al., 2012).

\begin{tabular}{|c|c|c|c|c|c|c|c|}
\hline Reagent purpose & Detail & Source & $\begin{array}{l}\text { Predicted } \\
\text { MW, kDa }\end{array}$ & Epitope & [used] & $\begin{array}{l}\text { Peptide } \\
\text { availability }\end{array}$ & Raised in \\
\hline \multirow[t]{6}{*}{ Primary antibodies } & $\mathrm{Kv} 7.1 / \mathrm{KCNQ} 1$ & Pineda Antikörper-Service, Germany & 75 & $\mathrm{~N}$-terminus & $1: 100$ & No & Rabbit \\
\hline & $\mathrm{Kv} 7.4 / \mathrm{KCNQ} 4$ & NeuroMab, cat no $75-082,1 \mathrm{mg} / \mathrm{ml}$ & 77 & Hu aa 2-77, clone N4/36 lgG & $1: 200(5 \mu \mathrm{g} / \mathrm{ml})$ & No & Mouse \\
\hline & $\mathrm{Kv} 7.4 / \mathrm{KCNQ}^{*}$ & Abcam, ab65797, lot GR94754, whole serum & 77 & N' domain & 1:100 not available & No & Rabbit \\
\hline & $\mathrm{Kv7.5/KCNQ5^{ \star }}$ & Millipore ABN1372-q2476155; $1 \mathrm{ml} / \mathrm{ml}$ & $\sim 103$ & Human $\lg G$ & $1: 100(10 \mu \mathrm{g} / \mathrm{ml})$ & No & Rabbit \\
\hline & PECAM-1/CD31 & Santa Cruz Biotechnology, Sc-1506, $200 \mu \mathrm{g} / \mathrm{ml}$ & 130 & 699-727 aa at the C-terminus & $1: 100(2 \mu \mathrm{g} / \mathrm{ml})$ & - & Goat \\
\hline & SM- $\alpha$-actin & Sigma Aldrich A2547 & $\sim 42$ & $\mathrm{~N}$-terminal & (1:100) not available & - & Mouse \\
\hline \multirow{2}{*}{$\begin{array}{l}\text { Nuclear labels/cell patency } \\
\text { markers }\end{array}$} & DAPI, Vectasheild & Vectorlabs & - & Nucleic acid & & - & - \\
\hline & propidium iodide (PI) & Sigma, P4170 & - & Nucleic acid & $10 \mathrm{nM}$ & - & - \\
\hline \multirow{3}{*}{$\begin{array}{l}\text { Immuno-histochemistry } \\
\text { secondary antibodies }\end{array}$} & Mouse 568 & Abcam, ab175700, lot GR320062-4, 2 mg/ml & - & $\lg G$ & $1: 100(20 \mu \mathrm{g} / \mathrm{ml})$ & - & Donkey \\
\hline & Rabbit 546 & Thermofisher, A-11035 & - & $\lg G$ & $1: 100(20 \mu \mathrm{g} / \mathrm{ml})$ & - & Goat \\
\hline & Rabbit 633 & Merck, SAB4600132, lot 15C0423, 2 mg/ml & - & $\lg G$ & $1: 100(20 \mu \mathrm{g} / \mathrm{ml})$ & - & Donkey \\
\hline \multirow{3}{*}{$\begin{array}{l}\text { Immuno-cytochemistry } \\
\text { secondary antibodies }\end{array}$} & Mouse 488 & Thermofisher, A21202, 2 mg/mL & - & $\lg G$ & $1: 100(0.02$ mg/ml) & - & Donkey \\
\hline & Rabbit 568 & Thermofisher, A10042, 2 mg/mL & - & $\lg G$ & $1: 100(0.02$ mg/ml) & - & Donkey \\
\hline & Goat 633 & Thermofisher, A21082, $2 \mathrm{mg} / \mathrm{mL}$ & - & $\lg G$ & $1: 100(0.02$ mg/ml) & - & Donkey \\
\hline \multirow[t]{2}{*}{ Isotype controls } & Mouse lgG & ThermoFisher, $10400 \mathrm{C}$ & - & $\lg G$ & $5 \mathrm{mg} / \mathrm{ml}$ & - & Mouse \\
\hline & Rabbit lgG & ThermoFisher, S31235 & - & $\lg G$ & $10 \mathrm{mg} / \mathrm{ml}$ & - & Rabbit \\
\hline \multirow{2}{*}{$\begin{array}{l}\text { Immunoelectron microscopy } \\
\text { secondary antibodies }\end{array}$} & $5 \mathrm{~nm} \mathrm{Au}$ anti- rabbit & Merck, G7277, lot SLB3882V & - & $\lg G$ & $1: 100$ & - & Goat \\
\hline & $10 \mathrm{~nm} \mathrm{Au}$ anti- rabbit & Merck, G7402 & - & $\lg G$ & $1: 100$ & - & Goat \\
\hline
\end{tabular}

CD31, cluster of differentiation 31; DAPI, 4, 6-diamidino-2-phenylindole; PECAM, platelet endothelial cell adhesion molecule. 


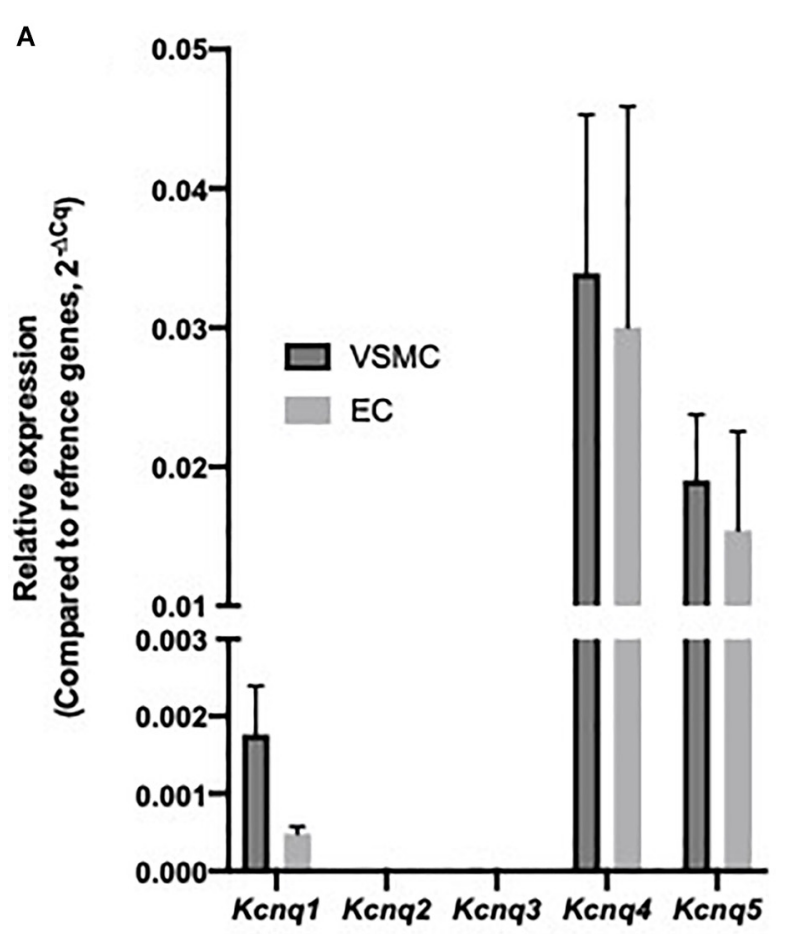

B

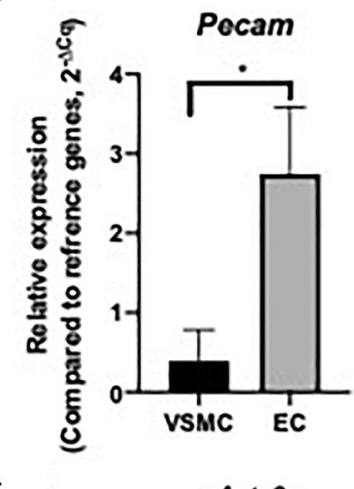

C

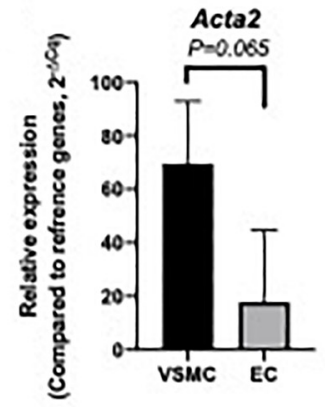

FIGURE 1 | Expression profile of Kcnq genes within isolated rat mesenteric vascular smooth muscle cells (VSMCs) and endothelial cells (ECs). RT-qPCR analysis of relative expression of Kcnq1-5 in isolated VSMCs and ECs (A). Cell specific markers Acta2 and Pecam, for VSMCs and ECs respectively, were measured to determine sample purity $(\mathbf{B}, \mathbf{C})$. Values expressed as mean \pm SEM of $\left(2^{-\Delta C q}\right)$ of $\Delta$ Cq values generated from appropriate housekeeper genes $(n=3)$. Statistical significance is defined as ${ }^{*} P<0.05(\mathbf{B}, \mathbf{C})$.

stacks were collected at $0.2 \mu \mathrm{m}$ intervals. The optimal rinsing protocol was determined by incubating in secondary only; and rinsing after successive 5 min incubations until fluorescence was reduced to background. Note that if this was not done secondary alone was specifically and highly localized to IEL hole sites; as potential false positives at such sites; suggesting that such sites have an affinity for IgG-secondary label alone.

\section{Electron Microscopy}

Animals were anesthetized as above and perfusion fixed in $0.2 \%$ glutaraldehyde and $2 \%$ paraformaldehyde in $0.1 \mathrm{~mol}-$ $\mathrm{L}^{-1}$ PBS ( $\mathrm{pH}$ 7.4). MA segments ( $\sim 2 \mathrm{~mm}$ in length) were washed $(3 \times 5 \mathrm{~min})$ and processed in a Leica EMPACT 2 high-pressure freezer using $0.7 \%$ low melting agarose as a cryoprotectant. Samples were then freeze-substituted in a Leica AFS2 into $0.2 \%$ uranyl acetate in $95 \%$ acetone (from -85 to $-50^{\circ} \mathrm{C}$ ) and infiltrated with Lowicryl (at $-50^{\circ} \mathrm{C}$ ), before UV polymerization (2 days each at -50 and $20^{\circ} \mathrm{C}$; Zechariah et al., 2020). Conventional transmission electron microscopy (TEM) was conducted using standard procedures (Sandow et al., 2002, 2004).

Individual serial transverse sections $(\sim 100 \mathrm{~nm})$ were mounted on Formvar-coated slot grids and processed for antigen localization as for confocal immunohistochemistry (per above and Table 2). The secondary used was 5 or $10 \mathrm{nmol}-\mathrm{L}^{-1}$ colloidal gold-conjugated antibody $(1: 40 ; 2 \mathrm{~h})$ in $0.01 \%$ Tween-20. Sections were imaged at $\mathrm{x} 10-40,000$ on a JEOL transmission electron microscope at $16 \mathrm{MP}$ (Emsis, Morada G3). Background gold label density was determined from randomly selected (4x) $1 \times 1 \mu \mathrm{m}$ regions per sample of lumen and IEL, compared to the same sized regions of interest in EC profiles.

\section{Wire Myography}

Second order MA segments ( $\sim 2 \mathrm{~mm}$ in length) were mounted on $40 \mu \mathrm{m}$ diameter tungsten wire in a tension myograph chamber (Danish Myo Technology, Arhus, Denmark) containing $5 \mathrm{~mL}$ of PSS (composition, as above) oxygenated with $95 \% \mathrm{O}_{2}$ and $5 \% \mathrm{CO}_{2}$ at $37^{\circ} \mathrm{C}$. Vessels then underwent a passive force normalization process to achieve an internal luminal circumference at a transmural pressure of $100 \mathrm{mmHg}$ $(13.3 \mathrm{kPa})$ to standardize pre-experimental conditions (Mulvany and Halpern, 1976). Force generated was first amplified by a PowerLab (ADInstruments, Oxford, United Kingdom), and recorded by LabChart software (ADInstruments, Oxford, United Kingdom). Vessels were then challenged with $60 \mathrm{mmol}-$ $\mathrm{L}^{-1}\left[\mathrm{~K}^{+}\right]$to determine viability, and then constricted with $10 \mu$ mol- $\mathrm{L}^{-1}$ methoxamine (MO), an $\alpha-1$ adrenoreceptor agonist, EC integrity was then determined via addition of $10 \mu$ mol- $\mathrm{L}^{-1}$ carbachol (CCh), a synthetic acetylcholine analog. Vessels displaying $\geq 90 \%$ vasorelaxation in response to CCh were considered EC positive (EC+). Vessels were denuded of ECs by gently passing a human hair through the lumen. Vessels expressing $\leq 10 \%$ vasorelaxation in response to $\mathrm{CCh}$ were considered EC negative (EC-). During functional investigations, 


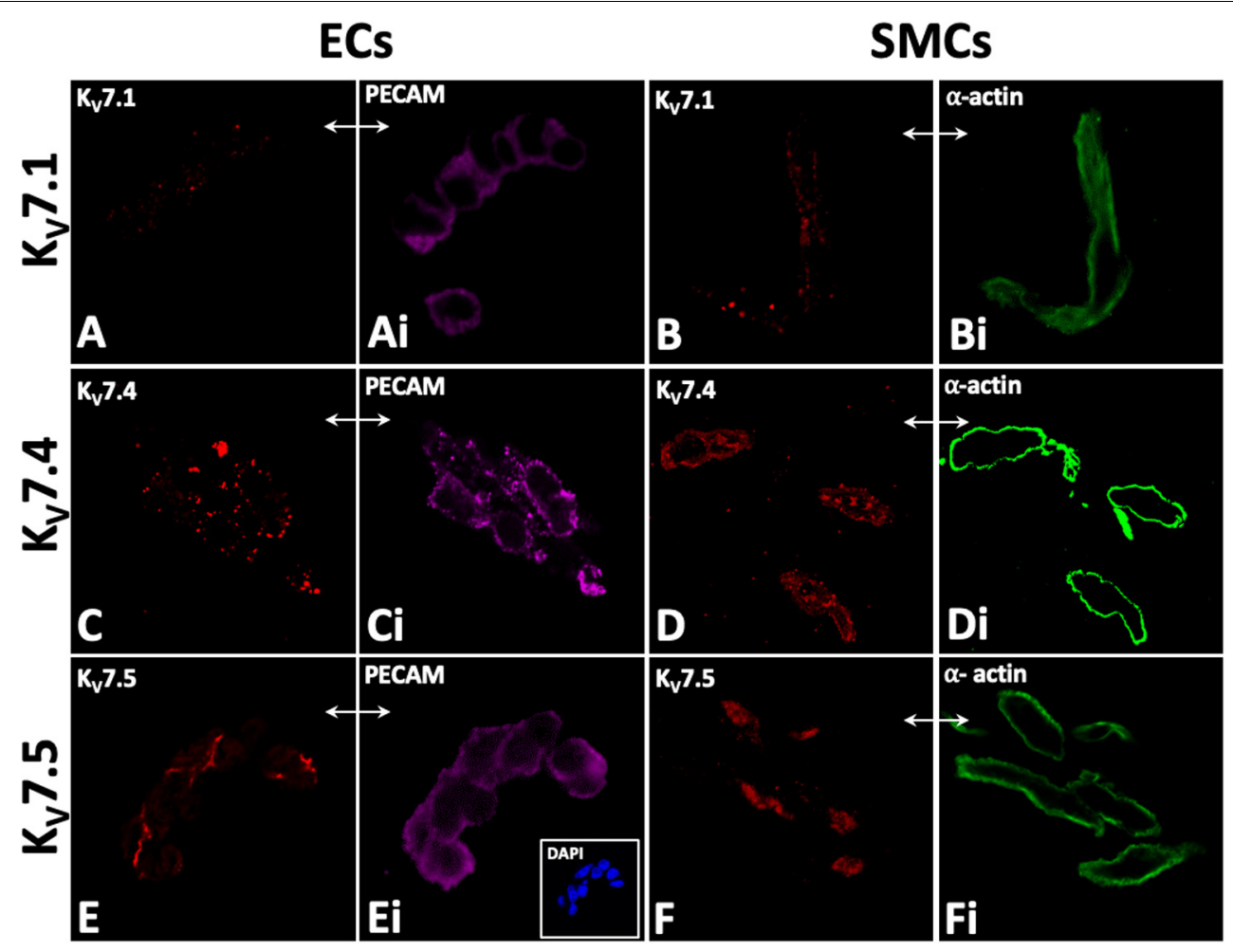

FIGURE 2 | Immunocytochemistry demonstrates $\mathrm{K}_{\mathrm{V}} 7.1, \mathrm{~K}_{\mathrm{V}} 7.4$, and $7 \mathrm{~V} .5$ localization in rat mesenteric artery isolated endothelial (EC; $\mathbf{A}$,C,E) and smooth muscle cells (SMC; B,D,F). Punctate labelling for Kv7.1, Kv7.4, and 7.5 was present in isolated EC and SMCs (A,C,E and B,D,F). PECAM and smooth muscle a-actin were used as markers for isolated endothelial and smooth muscle cells, respectively (Ai,Ci,Ei and $\mathbf{B i}, \mathbf{D i}, \mathbf{F i}$ respectively); e.g. comparative-same cells, double arrows, A-Fi). 4',6-diamidino-2-phenylindole (DAPI; e.g. inset, C) were used as nuclear markers to verify cell patency. $n=4-6$, representative of different source tissue (A-Fi). Double arrows from insets indicate same panel as main, but to different marker.

all vessels were pre-constricted with the thromboxane A2 receptor agonist U46619 (300 nmol- $\mathrm{L}^{-1}$ ) to elicit an $\mathrm{EC}_{80}$ contraction. Concentration-dependent relaxant responses to $\mathrm{S}-1$ (0.1-10 $\mu$ mol-L $\left.{ }^{-1}\right)$, ML213 (0.1-10 $\left.\mu \mathrm{mol}_{-} \mathrm{L}^{-1}\right)$, ML277 (0.03-10 $\left.\mu \mathrm{mol}-\mathrm{L}^{-1}\right)$, CCh $\left(0.3-10 \mu \mathrm{mol}^{-\mathrm{L}^{-1}}\right)$ and $S$-nitroprusside (SNP; 0.01-3 $\mu \mathrm{mol}-\mathrm{L}^{-1}$ ) were determined in the presence and absence of ECs, linopirdine (10 $\mu$ mol- $\left.\mathrm{L}^{-1}\right)$, HMR-1556 (10 $\left.\mu \mathrm{mol}-\mathrm{L}^{-1}\right)$, carbenoxolone $\left(100 \mu \mathrm{mol}-\mathrm{L}^{-1}\right)$, ML133 $\left(20 \mu \mathrm{mol}-\mathrm{L}^{-1}\right)$, barium chloride $\left(\mathrm{BaCl}_{2} ; 100 \mu \mathrm{mol}-\mathrm{L}^{-1}\right)$, L-nitroarginine methyl ester (L-NAME; $100 \mu$ mol-L ${ }^{-1}$ ), TRAM34 (1 $\mu$ mol-L ${ }^{-1}$ ), Apamin (10 nmol- $\left.\mathrm{L}^{-1}\right)$, 4-aminopyridine (4-AP; $\left.1 \mathrm{mmol}^{-1} \mathrm{~L}^{-1}\right)$, and tetraethylamonium (TEA; 1 mmol- $\left.\mathrm{L}^{-1}\right)$.

\section{Data and Statistical Analysis}

All functional figures express mean data from at least 5 animals \pm standard error of the mean (SEM). Experiments comparing groups of unequal numbers are present due to technical failure or expiry of tissue during isometric tension recording. For functional experiments involving cumulative concentrations, a transformed data set was generated using; $\mathrm{X}=\log (\mathrm{X})$, to reduce representative skew. A four parametric linear regression analysis was then performed using the following equation; [Log(Agonist) vs. response - variable slope (four parameters bottom/hillslope/top/EC 50 )] using GraphPad Prism (Version 8.2.0) to fit a concentration effect curve (CEC) to the figure. For data comparing multiple groups, a two way-ANOVA followed by a post hoc Bonferonni test in order to account for type 1 errors in multiple comparisons was performed for comparison of mean values. For data comparing two groups, an unpaired parametric T-test was was performed. Significance values are represented as follows; $P<0.05\left(^{*}\right) . n=(\mathrm{x})$, number of animals used. $N=(\mathrm{x})$, number of segments used. The data and statistical analysis comply with the recommendations on experimental design and analysis in pharmacology (Curtis et al., 2018).

\section{RESULTS}

\section{Identification of $\mathrm{K}_{\mathrm{V}} \mathbf{7}$ Channels Within MA ECs}

Initial investigation sought to identify $K c n q / \mathrm{K}_{\mathrm{V}} 7$ transcript and protein within MA ECs. Transcript levels for Kcnq1-5 and EC and VSMC markers were determined in cell lysates from isolated MA VSMC and EC (per Methods). Both ECs and VSMCs expressed Kcnq4>Kcnq5>Kcnq1 with no expression of Kcnq2/3 (Figure 1A) similar to previous studies (Ohya et al., 2003; Yeung et al., 2007; Ng et al., 2011). However, a comparative reduction in the relative abundance of Kcnq1 was observed in MA ECs when compared to VSMCs (Figure 1A). Cell isolation efficiency is demonstrated by a reduction in EC marker Pecam 
within VSMCs cell lysates when compared to ECs $(P \leq 0.05)$ and a reduction in VSMCs marker Acta2 in EC cell lysates when compared to VSMCs $(P=0.065$, Figures 1B,C).

$\mathrm{K}_{\mathrm{V}} 7.1, \mathrm{~K}_{\mathrm{V}} 7.4$, and $\mathrm{K}_{\mathrm{V}} 7.5$ were detected in isolated ECs by immunodetection (Figures $2 \mathrm{~A}, \mathrm{C}, \mathrm{E}$ ). $\mathrm{K}_{\mathrm{V}} 7.4$ had a punctate distribution in isolated ECs (Figure 2C) whereas $\mathrm{K}_{V} 7.5$ label appeared to be predominantly cytoplasmic with some diffuse label around the nucleus (Figure 2E). Similar to previous reports (Zhong et al., 2010; Oliveras et al., 2014; Mills et al., 2015; Morales-Cano et al., 2015; Barrese et al., 2018a). KV7.1, $\mathrm{K}_{\mathrm{V}} 7.4$, and 7.5 were also identified in isolated MA VSMCs (Figures 2B,D,F). $\mathrm{K}_{\mathrm{V}} 7.1$ staining in ECs was negligible compared to VMSCs (Figures 2A,B). ECs and VSMCs were identified by positive expression of either PECAM (Figures 2Ai,Ci,Ei) or $\alpha$-actin (Figures $2 \mathbf{B i}, \mathbf{D i}, \mathbf{F i}$ ) respectively. Antibody specificity was determined via positive staining in $\mathrm{CHO}$ cells transfected with purported target and negative staining in non-transfected control cells (Supplementary Figure 1). Importantly, as ion channel expression can alter in isolated cells $\mathrm{K}_{\mathrm{V}} 7.4$ and $\mathrm{K}_{\mathrm{V}} 7.5$ were also detected in both ECs and VSMCs in en face wholemount arteries (Figures 3A,B,E,F). Notably, both $\mathrm{K}_{\mathrm{V}} 7.4$ and 7.5 were expressed at a proportion of IEL hole sites at an apparently higher level than the associated EC membrane label (Figures 3C,D,G,H). We also detected $\mathrm{K}_{\mathrm{V}} 7.4$ and $\mathrm{K}_{\mathrm{V}} 7.5$ in EC by immuno-gold electron microscopy (Supplementary Figure 2). These studies identify $\mathrm{K}_{\mathrm{V}} 7.4$ and $\mathrm{K}_{\mathrm{V}} 7.5$ in ECs as well as smooth muscle cells.

\section{Removal of ECs Modulates K $7.2-5$ Activator Efficacy}

A comprehensive pharmacological analysis was undertaken to determine if $\mathrm{K}_{\mathrm{V}} 7$ channels have a functional role in MA ECs via a reductive approach. Initially, the effects of $\mathrm{K}_{V} 7$ channel modulators were examined in endothelium intact or denuded MAs. The structurally dissimilar $\mathrm{K}_{\mathrm{V}} 7.2-7.5$ activators S-1 and ML213 interact with the same pharmacophore centered around a tryptophan in the S5 domain (Schenzer, 2005; Bentzen et al., 2006; Brueggemann et al., 2014; Jepps et al., 2014). ML277 is a potent activator of $K_{V} 7.1$ (Yu et al., 2013) with a 100 -fold increase in selectivity for $\mathrm{K}_{\mathrm{V}} 7.1$ compared to $\mathrm{K}_{\mathrm{V}} 7.2-5$ (Yu et al., 2013). Consistent with previous findings (Chadha et al., 2012; Jepps et al., 2014), S-1- and ML213mediated vasorelaxation was ablated by pre-incubation with $10 \mu$ mol- $\mathrm{L}^{-1}$ of the pan- $\mathrm{K}_{\mathrm{V}} 7$ channel inhibitor linopirdine (Schnee and Brown, 1998; Figures 4A,B,D). Relaxation produced by $10-300 \mathrm{nmol}^{-1}$ ML277 were also prevented by preincubation with linopirdine (Figure 4C). However, relaxation produced by concentrations $>1 \mu \mathrm{mol}-\mathrm{L}^{-1}$ ML277 was not attenuated by linopirdine and are therefore not mediated by $\mathrm{K}_{\mathrm{V}} 7.1$ activation.

Endothelial removal for the following experiments was confirmed by ablation of vasorelaxation in response to $10 \mu \mathrm{mol}-$ $\mathrm{L}^{-1} \mathrm{CCh}$ (Figure 5A). Endothelium denudation by mechanical abrasion has no impact on the peak contraction produced by 300 nmol-L $^{-1}$ U46619 (Figure 5B), but significantly attenuated the potency of S-1 mediated vasorelaxation increasing $\mathrm{EC}_{50}$ from

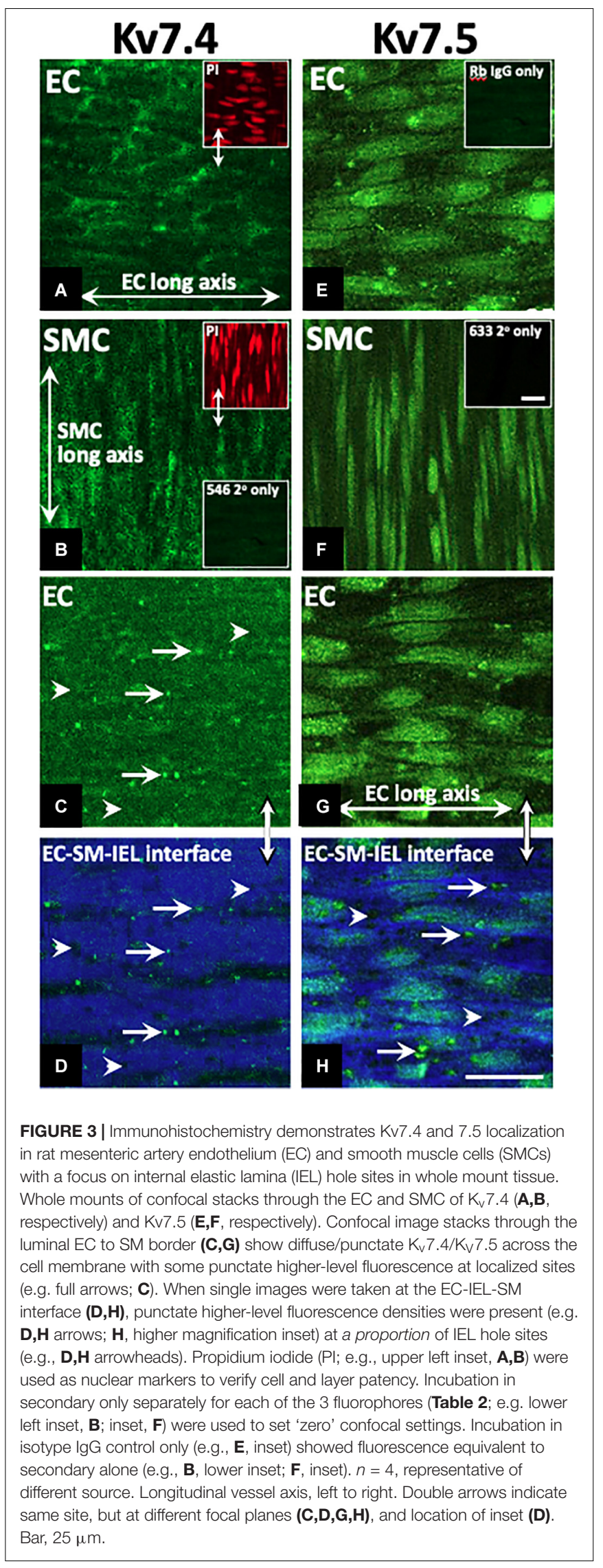



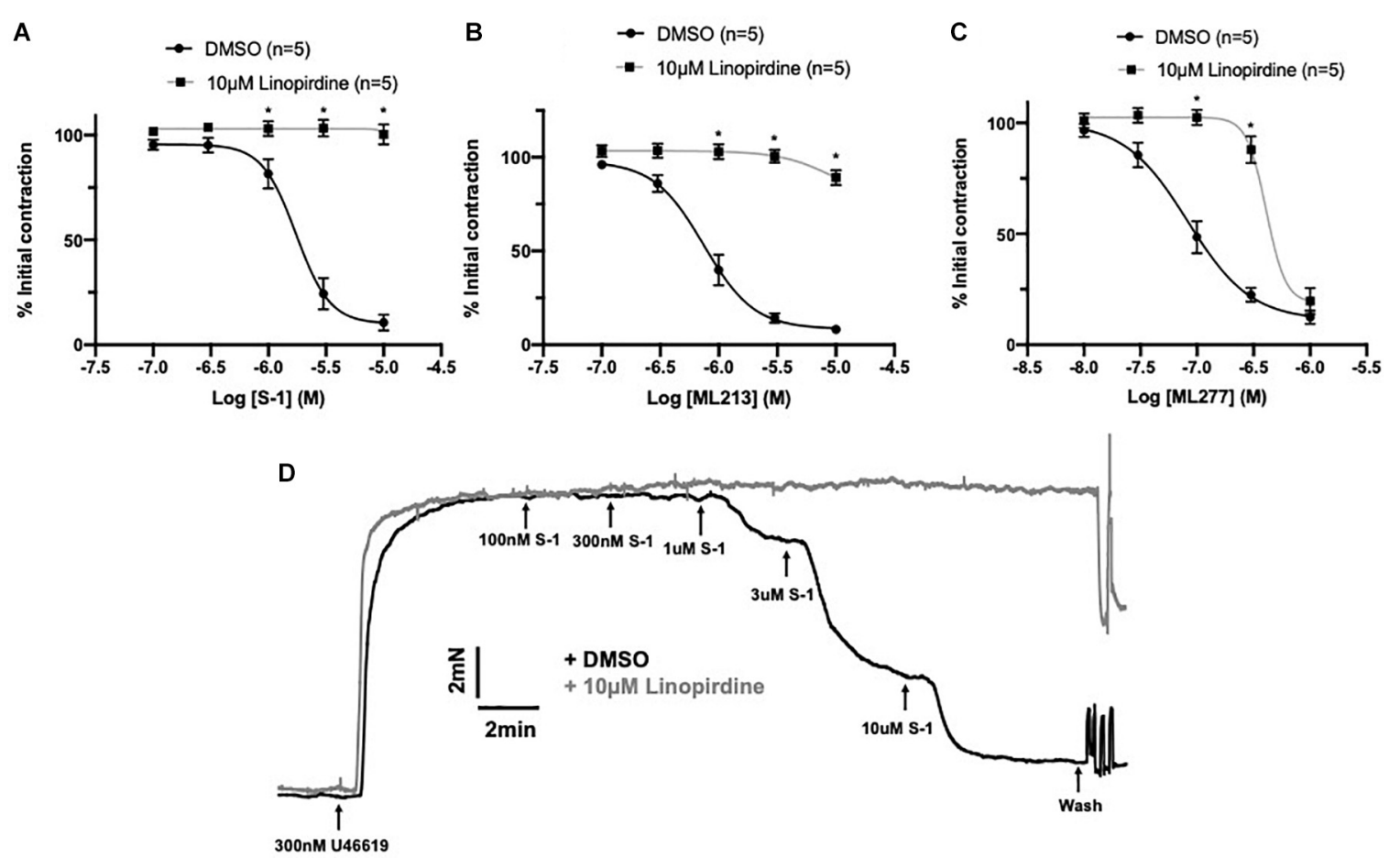

FIGURE 4 | Sensitivity of Kv7 activator relaxations to $10 \mu \mathrm{mol}-\mathrm{L}^{-1}$ linopirdine. In vessels pre-incubated in DMSO solvent control, KV7.2-5 channel activators S-1 and $\mathrm{ML} 213$ relax pre-constricted arterial tone (300 $\mathrm{nmol}-\mathrm{L}^{-1} \cup 46619$; black) and are ablated by pre-incubation with pan $\mathrm{K}_{V} 7 \mathrm{channel}$ inhibitor linopirdine (10 $\mu$ mol-L ${ }^{-1}$; gray; $\left.n=5 ; \mathbf{A}, \mathbf{B}\right)$. In vessels pre-incubated in DMSO solvent control, $\mathrm{K}_{\mathrm{V}} 7.1$ channel activator ML277 relaxes pre-constricted arterial tone (300 mol- $\mathrm{L}^{-1} \mathrm{U} 46619$; black) and is ablated by linopirdine (10 $\mu \mathrm{mol}-\mathrm{L}^{-1}$; gray) to a threshold of $300 \mathrm{nmol}-\mathrm{L}^{-1} \mathrm{ML} 277(\mathrm{n}=5$; $\mathbf{C})$. A representative trace of $\mathrm{S}$-1-mediated vasorelaxation $\pm 10 \mu \mathrm{mol}-\mathrm{L}^{-1}$ linopirdine (D). All values are expressed as mean $+\mathrm{SEM}$. A two-way statistical ANOVA with a post hoc Bonferroni test was used to generate significance values. Statistical significance is defined as ${ }^{*} P<0.05$ (A-C).

$2 \pm 0.2 \mu \mathrm{mol}-\mathrm{L}^{-1}$ to $3 \pm 0.7 \mu \mathrm{mol}-\mathrm{L}^{-1}$ (Figures 5C,D). S1 mediated relaxation was also impaired via the non-selective gap junction inhibitor carbenoxolone (Tare et al., 2002) (water $E_{\max }=6.11 \pm 1.82 \%$ vs. carbenoxolone $E_{\max }=18.7 \pm 3.25 \%$; Figure 5E). In addition, the potency of ML213 was also impaired by endothelial removal $\left(\mathrm{EC}(+) \mathrm{EC}_{50}=1 \pm 0.2 \mu \mathrm{mol}-\right.$ $\mathrm{L}^{-1}$ vs. $\mathrm{EC}(-) \mathrm{EC}_{50}=3 \pm 0.2 \mu \mathrm{mol}-\mathrm{L}^{-1}$; Figure $\left.5 \mathrm{~F}\right)$ in a fashion analogous to $\mathrm{S}-1$. However, the linopirdine-sensitive relaxation produced by ML277 was not affected by endothelial removal (Figure 5G).

\section{EC K $\mathrm{IR}_{\mathrm{R}}$ Channels Modulate KV7.2-5 Activator Sensitivity}

Having identified that the presence of the endothelium modulates responses to $\mathrm{K}_{\mathrm{V}} 7$ activators, experiments were performed to identify the underlying mechanism/s involved. Murine endothelial KCNJ2-encoded $\mathrm{K}_{\mathrm{IR}} 2.1$ channels have been identified as 'signal boosters' that enhance EC-derived relaxation (Sonkusare et al., 2016). Comparatively, the current literature regarding rat mesenteric $\mathrm{K}_{\mathrm{IR}} 2$ channels is limited. In brief, rat MA endothelium expresses $\mathrm{K}_{\mathrm{IR}} 2.1$ (Dora et al., 2008), inwardly rectifying $\mathrm{Ba}^{2+}$ sensitive channels are restricted to the endothelial layer (Crane et al., 2003a) and $\mathrm{K}_{\mathrm{IR}}$ channels contribute to acetylcholine-mediated responses (Goto et al.,
2004). We propose that like mice, rat mesenteric ECs express functional $\mathrm{K}_{\mathrm{IR}} 2$ channels that propagate EC signals in a similar process. Therefore, we performed a series of studies investigating the effect of two characterized $\mathrm{K}_{\mathrm{IR}} 2$ blockers, $\mathrm{BaCl}_{2}$ (Hagiwara et al., 1978) and ML133 (Wang et al., 2011) on $K_{V} 7$ activatormediated vasorelaxation.

In arteries with a functional endothelium, $\mathrm{K}_{\mathrm{IR}} 2$ blockers, $\mathrm{BaCl}_{2}\left(100 \mu \mathrm{mol}-\mathrm{L}^{-1}\right)$ and ML133 $\left(20 \mu \mathrm{mol}-\mathrm{L}^{-1}\right)$, significantly impaired relaxations produced by $\mathrm{S}-1$ (Figure 6A, $\mathrm{EC}_{50}=\mathrm{DMSO}$, $1.89 \pm 0.2 \mu \mathrm{mol}-\mathrm{L}^{-1} / \mathrm{BaCl}_{2}, \quad 2.3 \pm 0.31 \mu \mathrm{mol}-\mathrm{L}^{-1}$; Figure 6B, $\mathrm{EC}_{50}=\mathrm{DMSO}, 0.52 \pm 0.12 \mu \mathrm{mol}-\mathrm{L}^{-1} / \mathrm{ML} 133$, $3.1 \pm 1.5 \mu \mathrm{mol}-\mathrm{L}^{-1}$ ) and ML213 (Figures 6C,D, EC $50=\mathrm{DMSO}$, $0.9 \pm 0.3 \mu \mathrm{mol} / \mathrm{L}^{-1} / \mathrm{BaCl}_{2}, 2.2 \pm 0.5 \mu \mathrm{mol} / \mathrm{L}^{-1} / \mathrm{ML} 133$ $\left.2.5 \pm 0.25 \mu \mathrm{mol}-\mathrm{L}^{-1}\right)$ when compared to DMSO solvent control (Figures 6A-D). No attenuation of the response to ML277 was observed when pre-incubated with either blocker (Figures 6E,F), consistent with EC removal. Furthermore, in arteries where the endothelium had been removed neither ML133 nor $\mathrm{BaCl}_{2}$ had any effect on ML213 mediated relaxations (Figures 6G,H).

\section{$\mathrm{IK}_{\mathrm{Ca}} / \mathrm{SK}_{\mathrm{Ca}}$ Inhibitors Had No Impact on Kv7 Activator Mediated Relaxation}

Endothelial $\mathrm{IK}_{\mathrm{Ca}}$ and $\mathrm{SK}_{\mathrm{Ca}}$ channels contribute to relaxation responses in rat MA (Crane et al., 2003b). Thus, it is feasible that $\mathrm{K}_{\mathrm{V}} 7$ channels interact with other key endothelial 

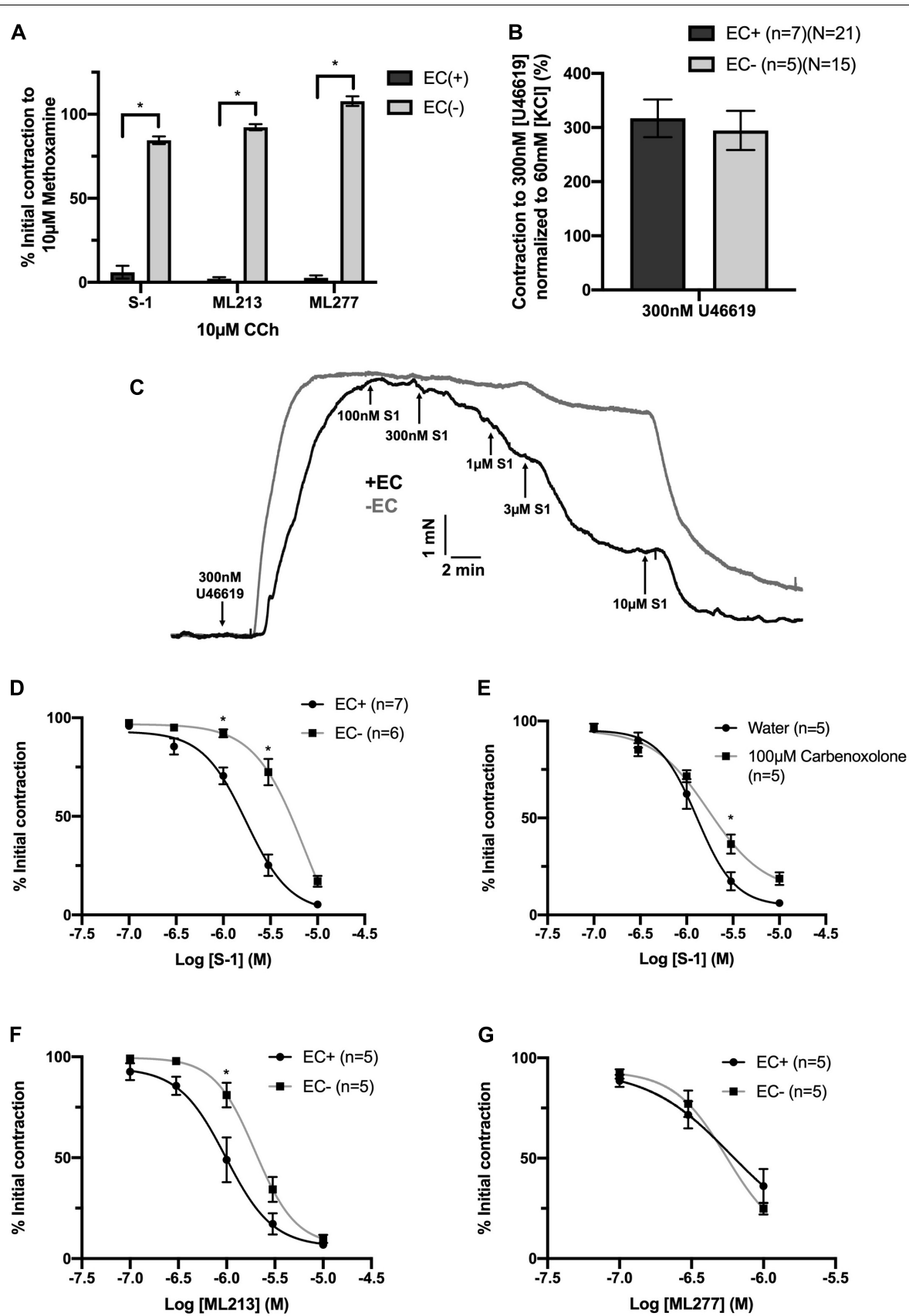

FIGURE 5 | KV 7.2-5 channel activator mediated vasorelaxation was significantly attenuated by EC removal. Removal of ECs ablated vasorelaxation in response to $10 \mu \mathrm{mol}-\mathrm{L}^{-1}$ CCh following pre-constriction with $10 \mu \mathrm{mol}-\mathrm{L}^{-1} \mathrm{MO}$ (A). Removal of ECs (gray) has no effect on vasoconstriction to U46619 (300 $\mathrm{nmol}-\mathrm{L}^{-1}$ ) when normalized to vasoconstriction to $\mathrm{KCl}\left(60 \mathrm{mmol}^{-1} ; n=5-7 ; n=15-21\right.$; B). Representative trace of EC S-1-mediated vasorelaxation in EC(-) denuded vessels

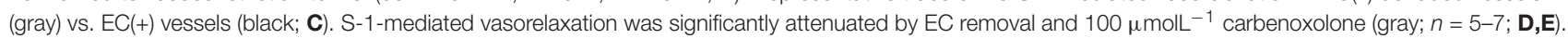
ML213 but not ML277-mediated vasorelaxation was significantly attenuated by EC removal (gray; $n=5-7$; D,E). Removal of ECs (gray) has no effect on ML277 within its range of linopirdine sensitivity $(n=5 ; \mathbf{F})$. All values are expressed as mean + SEM $(\mathbf{A}-\mathbf{G})$. A two-way statistical ANOVA with a post hoc Bonferroni test was used to generate significance values. Statistical significance is defined as ${ }^{*} P<0.05$ (A-G).

potassium channels; particularly those expressed within microdomains (Sandow et al., 2009). However, consistent with previous reports (Jepps et al., 2016), pre-incubation with a combination of $\mathrm{IK}_{\mathrm{Ca}}$ inhibitor TRAM-34 (1 $\mu$ mol- $\mathrm{L}^{-1}$; Wulff et al., 2000) and $\mathrm{SK}_{\mathrm{Ca}}$ inhibitor apamin (100 nmol- $\mathrm{L}^{-1}$;
Spoerri et al., 1975) had no effect on $\mathrm{K}_{\mathrm{V}} 7$ activator mediated vasorelaxation (Figures $7 \mathrm{~A}-\mathrm{C}$ ). These data suggest that the endothelium-dependent increase in potency to the $\mathrm{K}_{\mathrm{V}} 7$ activators involves endothelial $\mathrm{K}_{\mathrm{IR}}$, but not $\mathrm{IK}_{\mathrm{Ca}}$ or $\mathrm{SK}_{\mathrm{Ca}}$ channels. 


\section{$100 \mu \mathrm{M} \mathrm{BaCl}_{2}$}
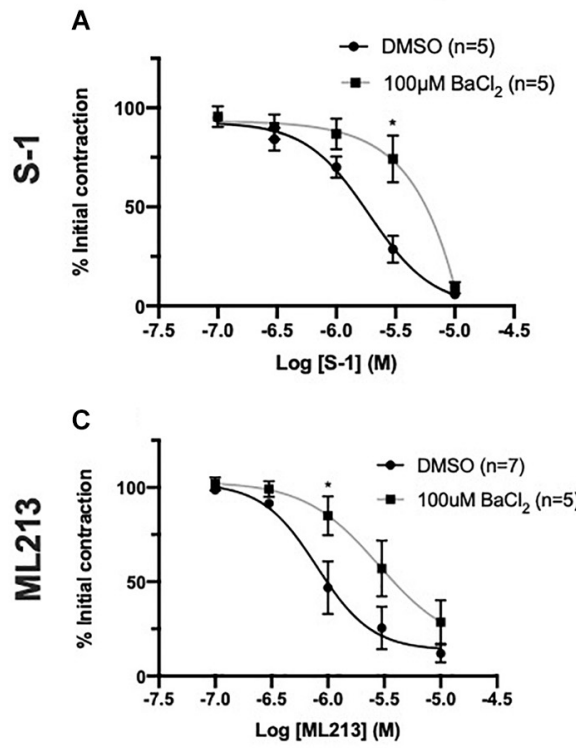

E

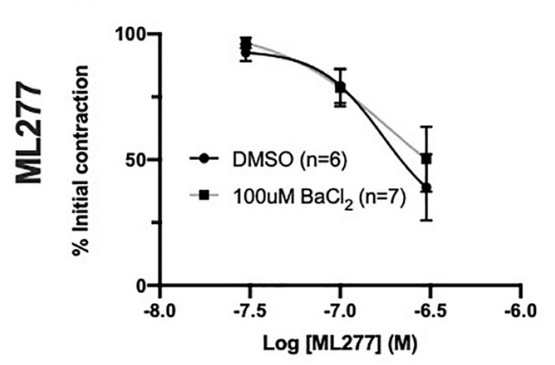

G

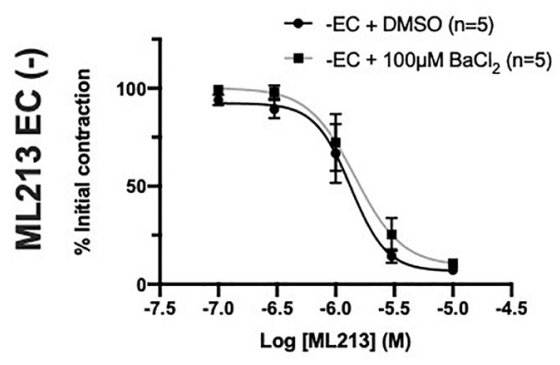

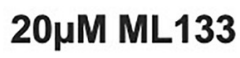

B

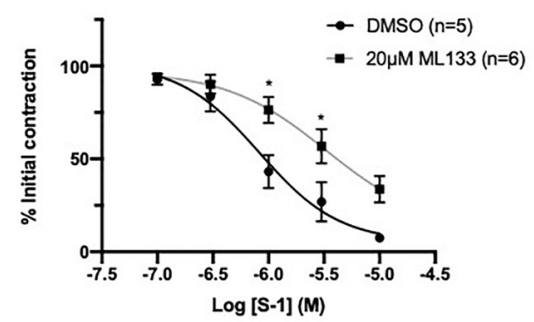

D

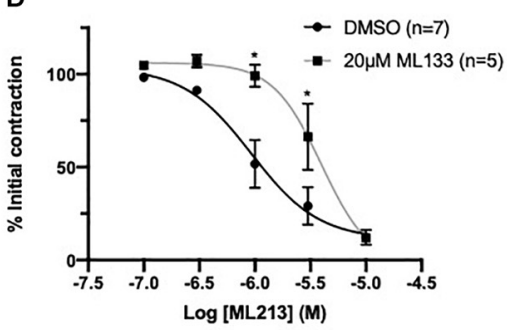

F

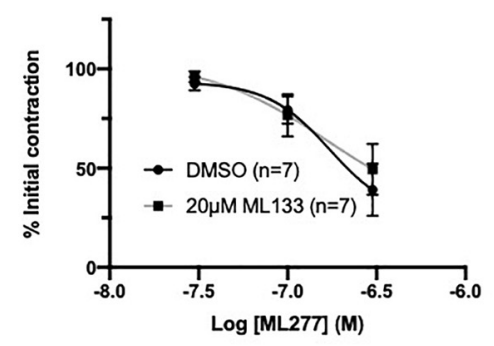

H

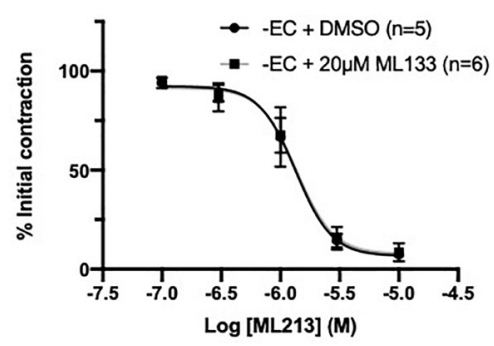

FIGURE 6 | $\mathrm{K}_{V} 7.2-5$ channel activator-mediated vasorelaxation was attenuated by two structurally different $\mathrm{K}_{\mathbb{R}}$ channel blockers, BaCl 2 and ML133, but not In EC denuded vessels. $\mathrm{K}_{\mathrm{V}} 7.2-5$ channel activator S-1 and ML213 effects were significantly attenuated by pre-incubation with the $\mathrm{K}_{\mathrm{IR}} 2$ channel inhibitor $\mathrm{BaCl}_{2}$ (100 $\mu$ mol-L ${ }^{-1}$; black; $\left.n=5-7 ; \mathbf{A}, \mathbf{C}\right) . K_{V} 7.2-5$ channel activator S-1 and ML213 effects were significantly attenuated by pre-incubation with a selective $\mathrm{K}_{\mathrm{Ir}} 2.1$ channel inhibitor, ML133 (20 $\mu$ mol-L ${ }^{-1}$; gray; $n=5-7$; B,D). KV7.1 channel activator ML277-mediated vasorelaxation was not affected by pre-incubation with either $\mathrm{BaCl}_{2}\left(100 \mu \mathrm{mol}-\mathrm{L}^{-1}\right)$ or ML133 $\left(20 \mu \mathrm{mol}-\mathrm{L}^{-1}\right.$; gray; $\left.n=6-7 ; \mathbf{E , F}\right)$. In EC denuded vessels, KV 7.2-5 channel activator ML213 responses were not affected by pre-incubation with either $\mathrm{K}_{\mathbb{R}} 2$ channel inhibitor $\mathrm{BaCl}_{2}\left(100 \mu \mathrm{mol}-\mathrm{L}^{-1}\right.$; gray; $\left.n=5 ; \mathbf{G}\right)$ or ML133 $\left(20 \mu \mathrm{mol}-\mathrm{L}^{-1}\right.$; gray; $\left.n=5-6 ; \mathbf{H}\right)$. All values are expressed as mean + SEM (A-H). A two-way statistical ANOVA with a post hoc Bonferroni test was used to generate significance values. Statistical significance is defined as ${ }^{*} P<0.05$ (A-H).

\section{Kv7 Channels Contribute to CCh Evoked Vasorelaxation}

The expression of functional $\mathrm{K}_{\mathrm{V}} 7$ channels within ECs begs the question - do they contribute to EC-derived responses? Acetylcholine produces endothelium-dependent relaxation through NO-, EDH- and prostanoid-dependent mechanisms in rat MA (Parsons et al., 1994; Shimokawa et al., 1996; Peredo et al., 1997).

A distinct rightward shift in the sensitivity to vasorelaxation in response to $\mathrm{CCh}$, a synthetic acetylcholine analog, was 

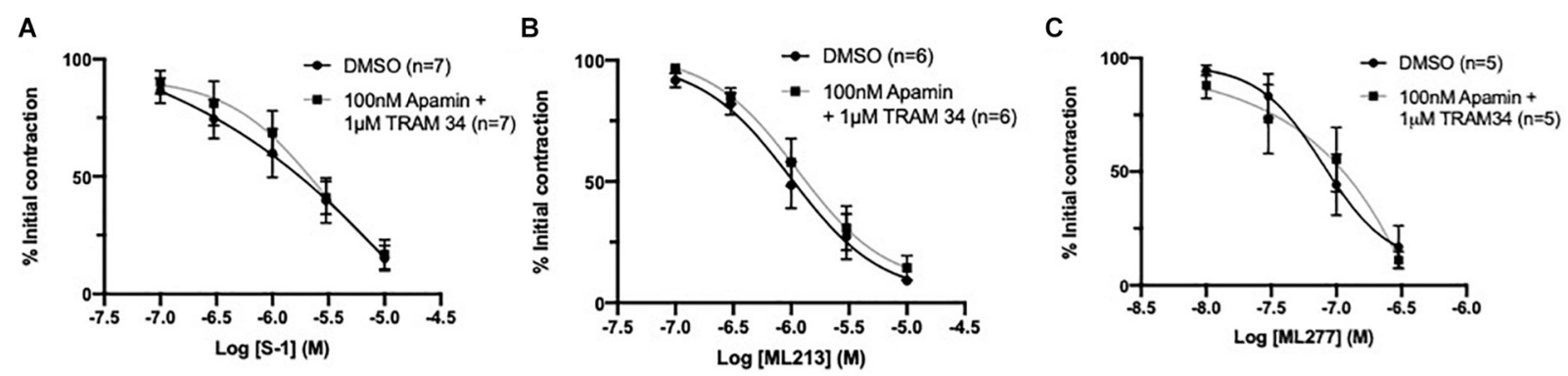

FIGURE $7 \mid K_{V} 7$ channel activator mediated vasorelaxation was not affected by preincubation with $\mathrm{IK}_{\mathrm{Ca}} / \mathrm{SK}_{\mathrm{Ca}}$ channel antagonists. Pre-incubation with both $1 \mathrm{~K}_{\mathrm{Ca}}$ channel inhibitor TRAM34 (1 $\left.\mu \mathrm{mol}-\mathrm{L}^{-1}\right)$ and SK $\mathrm{Ca}_{a}$ channel inhibitor Apamin $\left(100 \mathrm{nmol}-\mathrm{L}^{-1}\right)$ had no effect on S-1, ML213 nor ML277 mediated vasorelaxation $(n=5-7$; gray, A-C). All values are expressed are expressed as mean values \pm SEM. A two-way statistical ANOVA with a post hoc Bonferroni test was used to generate significance values; no significant values were observed (A-C).

produced by the eNOS inhibitor L-NAME $\left(100 \mu \mathrm{mol}-\mathrm{L}^{-1}\right)$ when compared to DMSO control $\left(\mathrm{EC}_{50} \mathrm{DMSO}=0.59 \pm 0.1 \mu \mathrm{mol}-\right.$ $\mathrm{L}^{-1} ; \quad \mathrm{L}-\mathrm{NAME}=0.94 \pm 0.1 \mu \mathrm{mol}_{-} \mathrm{L}^{-1} ;$ Figure $8 \mathrm{~A}$ ). A combination $\mathrm{IK}_{\mathrm{Ca}}$ and $\mathrm{SK}_{\mathrm{Ca}}$ inhibitors, TRAM-34 (1 $\mu$ mol$\left.\mathrm{L}^{-1}\right)$ and apamin (100 nmol- $\left.\mathrm{L}^{-1}\right)$ respectively, suppress $\mathrm{EDH}$ in rat $\mathrm{MA}$, and produced greater attenuation $\left(\mathrm{EC}_{50}\right.$ TRAM34/apamin $=1.5 \pm 0.7 \mu \mathrm{mol}-\mathrm{L}^{-1}$; Figure 8A) when compared to L-NAME. Pre-incubating vessels with the pan $\mathrm{K}_{\mathrm{V}} 7$ channel inhibitor linopirdine $\left(10 \mu \mathrm{mol}-\mathrm{L}^{-1}\right)$ significantly attenuated CCh-mediated relaxation when compared to DMSO control $\left(\mathrm{EC}_{50}\right.$ DMSO $=0.2 \pm 0.08 \mu \mathrm{mol}-\mathrm{L}^{-1}$; linopirdine $=0.7 \pm 0.3 \mu \mathrm{mol}-\mathrm{L}^{-1}$; Figure 8B). In contrast, pre-incubating vessels with either the $\mathrm{K}_{\mathrm{V}} 7.1$ specific inhibitor HMR-1556 $\left(10 \mu\right.$ mol- $\left.\mathrm{L}^{-1}\right)$ or a combination of non-specific $\mathrm{K}_{\mathrm{V}}$ channel inhibitors TEA (1 mmol- $\mathrm{L}^{-1}$; Choi et al., 1991) and 4-AP (1 mmol-L ${ }^{-1}$; Kurata and Fedida, 2006) had no significant effect on CCh-evoked vasorelaxation (Figures 8C,D).

Additionally, CCh-evoked relaxations were significantly attenuated in vessels pre-incubated in TRAM34/apamin $\left(1 \mu \mathrm{mol}-\mathrm{L}^{-1} / 100 \mathrm{nmol}-\mathrm{L}^{-1}\right)$ and linopirdine $(10 \mu \mathrm{mol}-$ $\mathrm{L}^{-1}$ ) compared to vessels only pre-incubated in TRAM34/apamin alone $\left(\mathrm{EC}_{50} \mathrm{DMSO}=0.24 \pm 0.05 \mu \mathrm{mol}-\right.$ $\mathrm{L}^{-1}$; $\quad$ TRAM34/Apamin $=0.27 \pm 0.03 \mu$ mol- $^{-1}$; TRAM34/Apamin + linopirdine $=0.61 \pm 0.2 \mu \mathrm{mol}-\mathrm{L}^{-1}$; Figure 8E). In contrast, linopirdine failed to attenuate $\mathrm{CCh}$ relaxation in arteries pre-incubated with L-NAME $(100 \mu \mathrm{mol}-$ $\mathrm{L}^{-1}$; Figure $8 \mathrm{~F}$ ), thus suggesting $\mathrm{K}_{\mathrm{V}} 7$ contribution to eNOS sensitive proportion of CCh-mediated relaxation.

Furthermore, the present data demonstrates that preincubation with linopirdine $\left(10 \mu \mathrm{mol}-\mathrm{L}^{-1}\right)$ has no effect on vasorelaxation produced by the NO-donor SNP (Figure 8G). However, in contrast with previous reports (Jepps et al., 2016), pre-incubation with L-NAME $\left(100 \mu \mathrm{mol}-\mathrm{L}^{-1}\right)$ significantly attenuated $\mathrm{K}_{\mathrm{V}} 7.2-5$ activator mediated vasorelaxation (Figure 8H).

\section{DISCUSSION}

The present study identified Kcnq1, Kcnq4, and Kcnq5 transcripts in EC marker expressing cells and the consequent $\mathrm{K}_{\mathrm{V}} 7.1$,
$\mathrm{K}_{\mathrm{V}} 7.4$, and $\mathrm{K}_{\mathrm{V}} 7.5$ protein in isolated and whole mount rat MA ECs/VSMCs. Functionally, the present study demonstrates that the relaxation produced by two structurally different $\mathrm{K}_{\mathrm{V}} 7.2$ 5 activators, but not a $K_{V} 7.1$ activator, were modulated by the presence of the endothelium and gap junction inhibition. Said relaxation was also sensitive to $\mathrm{K}_{\mathrm{IR}} 2$ inhibition, which was dependent on the presence of ECs, suggestive of a novel functional interaction between $\mathrm{K}_{\mathrm{V}} 7$ and endothelial $\mathrm{K}_{\mathrm{IR}} 2 . \mathrm{x}$ channels. Furthermore, the present data suggest that $\mathrm{K}_{\mathrm{V}} 7.4 / \mathrm{K}_{\mathrm{V}} 7.5$ channels contribute to the NO-mediated axis of CCh-evoked endothelium-dependent relaxation downstream of eNOS. Thus, $\mathrm{K}_{\mathrm{V}} 7$ channels are expressed in ECs, when pharmacologically upregulated, are functionally coupled to other EC potassium channels in rat MA and contribute to endothelium-derived responses.

\section{$K_{v} 7$ Channel Expression and Function Within ECs}

Kv7 channel modulators have considerable impact on arterial tone. In VSMCs, active $\mathrm{K}_{\mathrm{V}} 7$ channels hyperpolarize the membrane potential, decreasing voltage-dependent calcium channel (VDCC) open probability and extracellular calcium influx resulting in relaxation. Within rodent models, the pharmacopeia of $\mathrm{K}_{\mathrm{V}} 7$ channel modulators has revealed $\mathrm{K}_{\mathrm{V}} 7.4$ and 7.5 channels are; (1) key determinants of resting vascular tone via regulation of resting membrane potential; (2) upregulated during cGMP and cAMP/EPAC/PKA-mediated vasodilation; (3) suppressed via PKC-mediated vasoconstriction. Comparatively, no functional role for $\mathrm{K}_{\mathrm{V}} 7.1$ has been identified in arteries (see Barrese et al., 2018b; Byron and Brueggemann, 2018 for review). A caveat of these observations is a lack of differentiation between VSMCs and ECs. However, recently $\mathrm{K}_{\mathrm{V}} 7$ channels were identified in pig coronary artery ECs (Chen et al., 2016), the novel findings presented here expand on these findings and demonstrate $\mathrm{K}_{\mathrm{V}} 7$ transcript and channel expression, functional activity and contribution to EC-derived vasodilatory signaling cascades in rat MA endothelium.

In most arteries, the endothelium and smooth muscle are electrochemically linked via MEGJs formed from connexin proteins within heterocellular communicating microdomains 

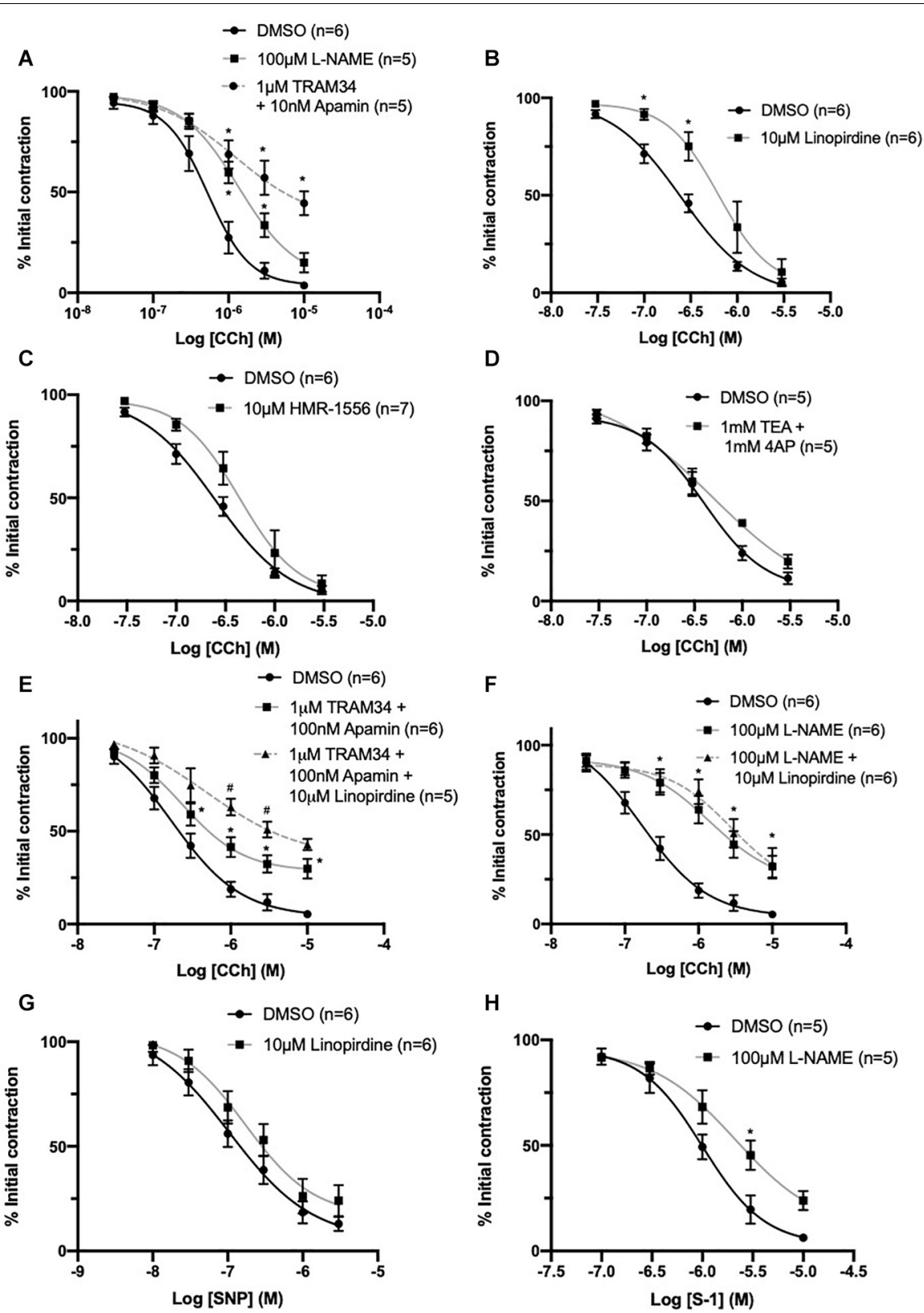

FIGURE 8 | CCh evoked vasorelaxation is mediated through both eNOS and $\mathrm{IK}_{\mathrm{Ca}} / \mathrm{SK}_{\mathrm{Ca}}$ channels and is partially attenuated by inhibition of $\mathrm{K}_{\mathrm{V}} 7$ channels upstream

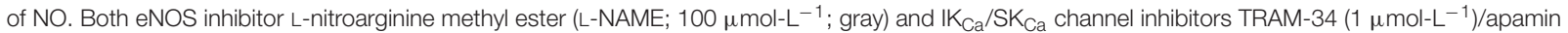
(100 nmol- $L^{-1}$; red, dashed line) significantly attenuated CCh mediated vasorelaxation $\left(n=5-6 ;\right.$ A). The pan $K_{V} 7$ channel inhibitor linopirdine (10 $\mu$ mol- $L^{-1}$; gray) significantly attenuated CCh mediated vasorelaxation ( $n=6$; B). The KV7.1 channel inhibitor HMR-1556 (10 $\mu$ mol-L ${ }^{-1}$; gray) did not modulate CCh-mediated vasorelaxation $(n=6 ; \mathbf{C})$. A combination of non-specific $\mathrm{K}^{+}$channel inhibitors 4-aminopyridine $\left(4-\mathrm{AP} ; 1 \mathrm{mmol}-\mathrm{L}^{-1}\right)$ and tetraethylammonium $\left(T E A ; 1\right.$ mmol-L ${ }^{-1}$; gray) did not modulate CCh-mediated vasorelaxation $(n=5$; $\mathbf{D})$. Additive attenuation to CCh-evoked relaxation in the presence of TRAM-34 (1 $\mu$ mol- $\left.L^{-1}\right) /$ apamin $\left(100 \mathrm{nmol}-\mathrm{L}^{-1}\right)+$ linopirdine $\left(10 \mu \mathrm{mol}-\mathrm{L}^{-1}\right.$; gray, dashed line) was observed when compared to vessels pre-incubated in only TRAM34/apamin (gray; $n=5-6$; E).

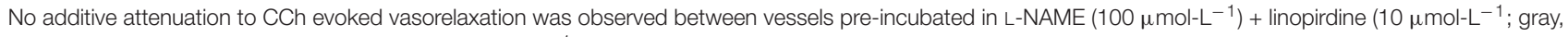
dashed line) when compared with L-NAME (100 $\mu$ mol-L ${ }^{-1}$; gray; $n=5$; F). SNP-mediated vasorelaxation was no effected by the pan-K 7 channel inhibitor linopirdine (10 $\mathrm{mmol}^{-\mathrm{L}^{-1}}$; gray) when compared to DMSO solvent control (black; G). KV 7.2-5 channel activator S-1 was significantly attenuated by pre-incubation with eNOS inhibitor L-NAME (100 $\mu \mathrm{mol}-\mathrm{L}^{-1}$; gray; $n=5$; $\left.\mathbf{H}\right)$. All values are expressed as mean + SEM. A two-way statistical ANOVA with a post hoc Bonferroni test was used to generate significance values $\left({ }^{*}\right.$, drug $\vee$ DMSO solvent control; \#=Group B vs. Group C) Statistical significance is defined as $\# /{ }^{*} P<0.05$ (A-H).

present within holes in the IEL (see Sandow et al., 2012 for review). Via these connections, current injection in to ECs passes into VSMCs (Sandow et al., 2002) supporting the presence of such coupling. The present data suggests a potential role for electrochemical heterocellular communication during $\mathrm{K}_{\mathrm{V}} 7.2-5$ activator-mediated vasorelaxation (Figure 9). This conjecture is 


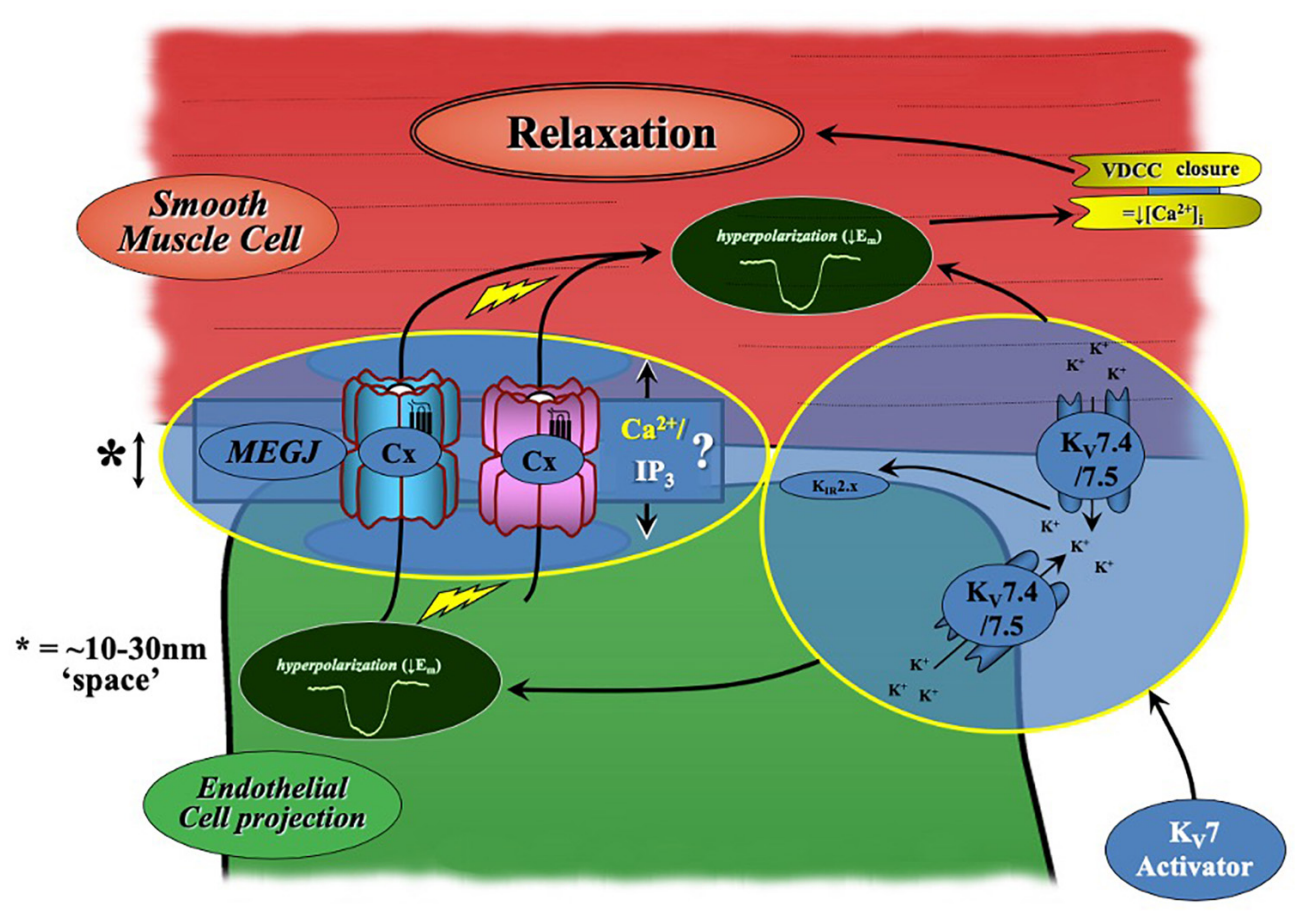

FIGURE 9 | Schematic of $K_{V} 7.2-5$ activator-mediated vasorelaxation. $K_{V} 7.2-5$ activator-mediated vasorelaxation occurs predominantly via $K_{V} 7.4 / 7.5$ activation within VSMCs. However, our findings suggest a novel contribution of endothelial- $K_{V} 7.4 / 7.5$ channels to $K_{v} 7.2-5$ activator mediated responses which augments relaxation. A process which is sensitive to both gap-junction and endothelial- $K_{\mathbb{R}} 2$.x inhibition (modified from Senadheera et al., 2012).

supported by apparently higher level expression of $\mathrm{K}_{\mathrm{V}} 7.4 / \mathrm{K}_{\mathrm{V}} 7.5$ in a proportion of IEL holes than that at the EC membrane as well as a significant attenuation of relaxation of pre-constricted arterial tone by two structurally different $\mathrm{K}_{\mathrm{V}} 7.2-5$ activators in the absence of ECs and presence of a (putative) gap junction inhibitor. In contrast, EC removal had no impact on $\mathrm{K}_{\mathrm{V}} 7.1$ activator-mediated vasorelaxation, which was observed in conjunction with reduced expression of Kcnq1 transcript and $\mathrm{K}_{\mathrm{V}} 7.1$ labeling within ECs compared to VSMCs. Collectively suggesting that only $\mathrm{K}_{\mathrm{V}} 7.4 / \mathrm{K}_{\mathrm{V}} 7.5$ channels of the $\mathrm{K}_{\mathrm{V}} 7$ sub-family are functionally expressed within MA ECs. An extrapolation of these results indicates a novel role for $\mathrm{K}_{\mathrm{V}} 7.4 / \mathrm{K}_{\mathrm{V}} 7.5$ channels in the regulation of EC membrane potential within myoendothelial projections. It is plausible, that localized $\mathrm{EC} \mathrm{K}_{\mathrm{V}} 7$ channels negate the influx of depolarization from VSMCs into the endothelium, providing tight regulation of $\mathrm{EC} \mathrm{V}_{\mathrm{m}}$ during VSMC contraction. However, further studies would be required to validate this hypothesis.

\section{A Novel Functional Interaction With Endothelial $\mathrm{K}_{\mathrm{IR}}$ Channels}

$\mathrm{K}_{\mathrm{IR}} 2$. $\mathrm{x}$ channels have been characterized in a variety of rat vascular beds including cerebral and coronary arteries (Smith et al., 2008), where their selective inhibition by $\mathrm{Ba}^{2+}$ revealed $\mathrm{K}_{\mathrm{IR}}$ channel amplification of a $\mathrm{K}^{+}$channel activator conductance (Smith et al., 2008). However, there is a degree of conflict regarding the role of $\mathrm{K}_{\mathrm{IR}} 2 . \mathrm{x}$ channels within rat MAs. As above, $\mathrm{Ba}^{2+}$ sensitive currents and $\mathrm{K}_{\mathrm{IR}} 2 . \mathrm{x}$ expression has been demonstrated in rat MA ECs (Crane et al., 2003a) which are purported to contribute to $\mathrm{K}_{\mathrm{Ca}}$ mediated-hyperpolarization during ACh-derived EC-dependent responses (Goto et al., 2004). In contrast, Smith et al. (2008) demonstrated that within 3rd order MAs, ACh-mediated $\mathrm{K}^{+}$conductance-dependent relaxation was insensitive to $\mathrm{Ba}^{2+}$, indicating that $\mathrm{K}_{\mathrm{IR}} 2 . \mathrm{x}$ channels do not augment $\mathrm{K}^{+}$conductance in these vessels during receptor-mediated vasodilation.

In the present study, significant attenuation of both S-1 and ML213 KV7.2-5 activator-mediated vasorelaxation was found following pre-incubation with two structurally different $\mathrm{K}_{\mathrm{IR}}$ 2.x blockers ML133 (Wu et al., 2010) and $\mathrm{Ba}^{2+}$ (Hagiwara et al., 1978) when compared to a solvent control. ML133 has been identified via high-throughput and mutagenesis investigation as a novel inhibitor of $\mathrm{K}_{\mathrm{IR}} 2.1$ channels via D172 and $\mathrm{I} 176$ residues within the M2 region of $\mathrm{K}_{\mathrm{IR}} 2.1$ (Wang et al., 2011) with an $\mathrm{IC}_{50}$ of $1.8 \mu$ mol- $\mathrm{L}^{-1}$ at $\mathrm{pH} 7.4$, with little to no effect against other $\mathrm{K}_{\mathrm{IR}}$ 2.x family members (Wu et al., 2010; Wang et al., 2011). Presently, ML133 is the most selective inhibitor of the $\mathrm{K}_{\mathrm{IR}} 2$ family. In analogous fashion to our endothelium denudation experiments, no effect was seen on the KV7.1 activator ML277mediated vasorelaxation; implying a specific interplay with $\mathrm{K}_{\mathrm{V}} 7.4$ and 7.5 channels. Furthermore, $\mathrm{K}_{\mathrm{IR}} 2$ blockers had no effect on $\mathrm{K}_{\mathrm{V}} 7.2-7.5$ activator-mediated relaxation in EC-denuded arteries, supporting the notion that functional $\mathrm{K}_{\mathrm{IR}} 2$ channels (in the rat MA bed) are restricted to the endothelium (Crane et al., 2003b). The present study suggests that pharmacological activation of 
endothelial $\mathrm{K}_{\mathrm{V}} 7.4 / 7.5$ channels also activates an endothelial $\mathrm{K}_{\mathrm{IR}} 2$ channels, increasing $\mathrm{K}^{+}$conductance, which in turn accounts for a proportion of $\mathrm{EC}$ augmentation of $\mathrm{K}_{\mathrm{V}} 7.2-5$ activator-mediated vasorelaxation (Figure 9). This may be due to a localized increase in potassium ion concentration in the proximity of the $\mathrm{K}_{\mathrm{IR}} 2$ channels or an alternative modulation. However, based on the findings described by Goto et al. (2004) and Smith et al. (2008), the collective data suggest that this phenomenon is dependent on the branch order of MA. Furthermore, it remains unclear if this occurs during receptor mediated signaling, or if it is only present during pharmacological activation of endothelial $\mathrm{K}_{\mathrm{V}} 7$ channels.

A primary concern for identification of novel functional interactions between ion channels using pharmacological tools is potential off-target effects. However, $\mathrm{K}_{\mathrm{V}} 7$ activator-mediated relaxation in vessels pre-incubated in $10 \mu \mathrm{mol}-\mathrm{L}^{-1}$ linopirdine was abolished. If S-1 or ML213 were activating non- $\mathrm{K}_{\mathrm{V}}$ channels such as $\mathrm{K}_{\mathrm{IR}}$, a degree of relaxation would still be observed in the presence of linopirdine. The present findings therefore suggest that both S-1 and ML213 work exclusively via $\mathrm{K}_{\mathrm{V}} 7$ channels and that attenuation of their response within rat MA occurs via a novel functional coupling of $\mathrm{K}_{\mathrm{V}} 7.4 / 7.5$ and $\mathrm{K}_{\mathrm{IR}} 2$ within ECs.

\section{The Contribution of $\mathrm{K}_{\mathrm{V}} 7$ Channels to CCh Evoked Relaxations Within Rat MA}

Our findings demonstrate that both NO- and EDH-dependent signaling contributes to CCh-mediated vasodilation, though the main contributor to endothelial-dependent vasodilation in 2nd order MA appears to be EDH, consistent with previous studies (Shimokawa et al., 1996). In light of the significant impact of $\mathrm{K}_{\mathrm{V}} 7$ inhibition on CCh-mediated vasorelaxation during the suppression of $\mathrm{EDH}$, the present study suggests that $\mathrm{K}_{\mathrm{V}} 7$ channels contribute to the eNOS sensitive axis of CCh-evoked relaxation within rat MA.

However, in a similar manner to rat renal artery (Stott et al., 2015), rat $\mathrm{MA} \mathrm{K}_{\mathrm{V}} 7$ channels do not represent downstream targets of NO signaling as $\mathrm{K}_{\mathrm{V}} 7$ inhibition does not impair NOdonor SNP-mediated relaxation. However, eNOS inhibition does impair relaxation to a $\mathrm{K}_{\mathrm{V}} 7$ activator, potentially implying $\mathrm{K}_{\mathrm{V}} 7$ channel involvement in the production or release of $\mathrm{NO}$ in response to CCh. Interestingly, this appears to be a vascular bed specific phenomenon, as L-NAME has no effect on $\mathrm{K}_{\mathrm{V}} 7$ activatormediated relaxation within rat penile artery (Jepps et al., 2016).

\section{Limitations}

Ideally, direct functional evidence for a functional role of $\mathrm{K}_{\mathrm{V}} 7$ channels in ECs would be provided by either single cell electrophysiology of sharp microelectrode impalement in whole arteries. However, this was not possible within the constraints of this study. Instead, we inferred a functional role for EC $\mathrm{K}_{\mathrm{v}} 7$ channels using a reductive approach, i.e., comparison of functional responses without or with EC ablation. These studies implicate $\mathrm{K}_{\mathrm{v}} 7$ channels as functional component of the EC physiology that merit consideration in future studies.

\section{CONCLUSION}

In conclusion, the present data reveal that mesenteric ECs express $\mathrm{K}_{\mathrm{V}} 7.4 / \mathrm{K}_{\mathrm{V}} 7.5$ channels and their presence boosts $\mathrm{K}_{\mathrm{V}} 7$ activator-mediated relaxation. Furthermore, the data indicated a novel functional interaction with endothelial $\mathrm{K}_{\mathrm{IR}} 2$ channels and support the proposition that endothelial $\mathrm{K}_{\mathrm{V}} 7$ channels contribute to endogenous endothelium-derived responses. These findings highlight the complex nature of the vascular response to $\mathrm{K}_{\mathrm{V}} 7$ channel upregulation and emphasize the importance of these channels to vascular signaling. The present data are consistent with $\mathrm{K}_{\mathrm{V}} 7$ channels representing a novel therapeutic target in endothelial dysfunction.

\section{DATA AVAILABILITY STATEMENT}

The original contributions presented in the study are included in the article/Supplementary Material, further inquiries can be directed to the corresponding author/s.

\section{ETHICS STATEMENT}

The animal study was reviewed and approved by UNSW Animal Ethics and Experimentation Committee (AEEC \#18/86B). For investigations performed at St George's University, London, investigators strictly adhered to the Animal (Scientific Procedures) Act 1986.

\section{AUTHOR CONTRIBUTIONS}

SB, SS, GM-P, and JS performed the research. IG and JS designed the research study. SS contributed essential reagents or tools. SB, SS, and GM-P analyzed the data. SB and IG wrote the manuscript. All the authors contributed to the article and approved the submitted version.

\section{FUNDING}

SB was funded by the British Heart Foundation (Grant \#FS/18/41/33762) awarded to IG.

\section{ACKNOWLEDGMENTS}

The authors would like to thank Miss Aditi Gunjal for her excellent assistance in wire myography.

\section{SUPPLEMENTARY MATERIAL}

The Supplementary Material for this article can be found online at: https://www.frontiersin.org/articles/10.3389/fphys.2020. 598779/full\#supplementary-material 


\section{REFERENCES}

Askew Page, H. R., Dalsgaard, T., Baldwin, S. N., Jepps, T. A., Povstyan, O., Olesen, S. P., et al. (2019). TMEM16A is implicated in the regulation of coronary flow and is altered in hypertension. Br. J. Pharmacol. 176, 1635-1648. doi: 10.1111/ bph.14598

Barrese, V., Stott, J. B., Figueiredo, H. B., Aubdool, A. A., Hobbs, A. J., Jepps, T. A., et al. (2018b). Angiotensin II Promotes $\mathrm{K}_{V} 7.4$ channels degradation through reduced interaction with HSP90. Hypertension 71, 1091-1100. doi: 10.1161/HYPERTENSIONAHA.118.11116

Barrese, V., Stott, J. B., and Greenwood, I. A. (2018a). KCNQ-encoded potassium channels as therapeutic targets. Ann. Rev. Pharmacol. Toxicol. 58, 625-648. doi: 10.1146/annurev-pharmtox-010617-052912

Bentzen, B. H., Schmitt, N., Calloe, K., Dalby Brown, W., Grunnet, M., and Olesen, S. P. (2006). The acrylamide (S)-1 differentially affects Kv7 (KCNQ) potassium channels. Neuropharmacology 51, 1068-1077. doi: 10.1016/j.neuropharm.2006. 07.001

Brueggemann, L. I., Cribbs, L. L., Schwartz, J., Wang, M., Kouta, A., and Byron, K. L. (2018). Mechanisms of PKA-dependent potentiation of Kv7.5 channel activity in human airway smooth muscle cells. Int. J. Mol. Sci. 12:2223. doi: 10.3390/ijms19082223

Brueggemann, L. I., Haick, J. M., Cribbs, L. L., and Byron, K. L. (2014). Differential activation of vascular smooth muscle Kv7.4, Kv7.5, and Kv7.4/7.5 channels by ML213 and ICA-069673. Mol. Pharmacol. 86, 330-341. doi: 10.1124/mol.114. 093799

Brueggemann, L. I., Moran, C. J., Barakat, J. A., Yeh, J. Z., Cribbs, L. L., and Byron, K. L. (2006). Vasopressin stimulates action potential firing by protein kinase C-dependent inhibition of KCNQ5 in A7r5 rat aortic smooth muscle cells. AJP Heart Circ. Physiol. 292, H1352-H1363. doi: 10.1152/ajpheart.00065.2006

Byron, K. L., and Brueggemann, L. I. (2018). Kv7 potassium channels as signal transduction intermediates in the control of microvascular tone. Microcirculation 25:e12419. doi: 10.1111/micc.12419

Chadha, P. S., Zunke, F., Zhu, H. L., Davis, A. J., Jepps, T. A., Olesen, S. P., et al. (2012). Reduced KCNQ4-encoded voltage-dependent potassium channel activity underlies impaired $\beta$-adrenoceptor-mediated relaxation of renal arteries in hypertension. Hypertension 59, 877-884. doi: 10.1161/ HYPERTENSIONAHA.111.187427

Chen, X., Li, W., Hiett, S. C., and Obukhov, A. G. (2016). Novel Roles for Kv7 channels in shaping histamine-induced contractions and bradykinindependent relaxations in Pig Coronary Arteries. PLoS One 11:e1048569. doi: 10.1371/journal.pone.0148569

Choi, K. L., Aldricht, R. W., Yellen, G., and Hughes, H. (1991). Tetraethylammonium blockade distinguishes two inactivation mechanisms in voltage-activated Ki channels. Proc. Natl. Acad. Sci. U. S. A. 88, 5092-5095. doi: 10.1073/pnas.88.12.5092

Crane, G. J., Gallagher, N., Dora, K. A., and Garland, C. J. (2003a). Smalland intermediate-conductance calcium-activated $\mathrm{K}+$ channels provide different facets of endothelium-dependent hyperpolarization in rat mesenteric artery. J. Physiol. 553(Pt 1), 183-189. doi: 10.1113/jphysiol.2003.051896

Crane, G. J., Walker, S. D., Dora, K. A., and Garland, C. J. (2003b). Evidence for a differential cellular distribution of inward rectifier $\mathrm{K}$ channels in the rat isolated mesenteric artery. J. Vasc. Res. 40, 159-168. doi: 10.1159/000070713

Curtis, M. J., Alexander, S., Cirino, G., Docherty, J. R., George, C. H., Giembycz, M. A., et al. (2018). Experimental design and analysis and their reporting II: updated and simplified guidance for authors and peer reviewers. Br. J. Pharmacol. 175, 987-993. doi: 10.1111/bph.14153

Dora, K. A., Gallagher, N. T., McNeish, A., and Garland, C. J. (2008). Modulation of endothelial cell KCa3.1 channels during endothelium-derived hyperpolarizing factor signaling in mesenteric resistance arteries. Circ. Res. 102, 1247-1255. doi: 10.1161/CIRCRESAHA.108.172379

Fukao, M., Hattori, Y., Kanno, M., Sakuma, I., and Kitabatake, A. (1997). Sources of $\mathrm{Ca} 2+$ in relation to generation of acetylcholine-induced endotheliumdependent hyperpolarization in rat mesenteric artery. Br. J. Pharmacol. 120, 1328-1334. doi: 10.1038/sj.bjp.0701027

Goto, K., Rummery, N. M., Grayson, T. H., and Hill, C. E. (2004). Attenuation of conducted vasodilatation in rat mesenteric arteries during hypertension: role of inwardly rectifying potassium channels. J. Physiol. 561(Pt 1), 215-231. doi: 10.1113/jphysiol.2004.070458
Grayson, T. H., Chadha, P. S., Bertrand, P. P., Chen, H., Morris, M. J., Senadheera, S., et al. (2013). Increased caveolae density and caveolin-1 expression accompany impaired NO-mediated vasorelaxation in diet-induced obesity. Histochem. Cell Biol. 139, 309-321. doi: 10.1007/s00418-012-1032-2

Greenberg, H. Z. E., Shi, J., Jahan, K. S., Martinucci, M. C., Gilbert, S. J., Ho, W. S., et al. (2016). Stimulation of calcium-sensing receptors induces endotheliumdependent vasorelaxations via nitric oxide production and activation of IKCa channels. Vasc. Pharmacol. 80, 75-84. doi: 10.1016/j.vph.2016.01.001

Hagiwara, S., Miyazaki, S., Moody, W., and Patlak, J. (1978). Blocking effects of barium and hydrogen ions on the potassium current during anomalous rectification in the starfish egg. J. Physiol. 279, 167-185. doi: 10.1113/jphysiol. 1978.sp012338

Howitt, L., Hilton Grayson, T., Morris, M. J., Sandow, S. L., and Murphy, T. V. (2012). Dietary obesity increases NO and inhibits BKCa-mediated, endothelium-dependent dilation in rat cremaster muscle artery: association with caveolins and caveolae. Am. J. Physiol. Heart Circ. Physiol. 302, H2464H2476. doi: 10.1152/ajpheart.00965.2011

Jepps, T. A., Bentzen, B. H., Stott, J. B., Povstyan, O. V., Sivaloganathan, K., Dalby-Brown, W., et al. (2014). Vasorelaxant effects of novel Kv7.4 channel enhancers ML213 and NS15370. Br. J. Pharmacol. 171, 4413-4424. doi: 10.1111/ bph.12805

Jepps, T. A., Chadha, P. S., Davis, A. J., Harhun, M. I., Cockerill, G. W., Olesen, S. P., et al. (2011). Downregulation of Kv7.4 channel activity in primary and secondary hypertension. Circulation 124, 602-611. doi: 10.1161/ CIRCULATIONAHA.111.032136

Jepps, T. A., Greenwood, I. A., Moffatt, J. D., Sanders, K. M., and Ohya, S. (2009). Molecular and functional characterization of $\mathrm{K}_{v} 7 \mathrm{~K}+$ channel in murine gastrointestinal smooth muscles. Am. J. Physiol. Gastrointest. Liver Physiol. 297, G107-G115. doi: 10.1152/ajpgi.00057.2009

Jepps, T. A., Olesen, S. P., Greenwood, I. A., and Dalsgaard, T. (2016). Molecular and functional characterization of Kv7 channels in penile arteries and corpus cavernosum of healthy and metabolic syndrome rats. Br. J. Pharmacol. 173, 1478-1490. doi: 10.1111/bph.13444

Khanamiri, S., Soltysinska, E., Jepps, T. A., Bentzen, B. H., Chadha, P. S., Schmitt, N., et al. (2013). Contribution of $\mathrm{K}_{\mathrm{V}} 7$ channels to basal coronary flow and active response to ischemia. Hypertension 62, 1090-1097. doi: 10.1161/ HYPERTENSIONAHA.113.01244

Kurata, H. T., and Fedida, D. (2006). A structural interpretation of voltage-gated potassium channel inactivation. Prog. Biophys. Mol. Biol. 92, 185-208. doi: 10.1016/j.pbiomolbio.2005.10.001

Mackie, A. R., Brueggemann, L. I., Henderson, K. K., Shiels, A. J., Cribbs, L. L., Scrogin, K. E., et al. (2008). Vascular KCNQ potassium channels as novel targets for the control of mesenteric artery constriction by vasopressin, based on studies in single cells, pressurized arteries, and in vivo measurements of mesenteric vascular resistance. J. Pharmacol. Exp. Ther. 325, 475-483. doi: 10.1124/jpet.107.135764

Mani, B. K., Robakowski, C., Brueggemann, L. I., Cribbs, L. L., Tripathi, A., Majetschak, M., et al. (2016). Kv7.5 potassium channel subunits are the primary targets for PKA-dependent enhancement of vascular smooth muscle Kv7 Currents. Mol. Pharmacol. 89, 323-334. doi: 10.1124/mol.115. 101758

McGuire, J. J., Ding, H., and Triggle, C. R. (2001). Endothelium-derived relaxing factors: a focus on endothelium-derived hyperpolarizing factor(s). Can. J. Physiol. Pharmacol. 79, 443-470. doi: 10.1139/y01-025

Mills, T. A., Greenwood, S. L., Devlin, G., Shweikh, Y., Robinson, M., Cowley, E., et al. (2015). Activation of $\mathrm{K}_{V} 7$ channels stimulates vasodilatation of human placental chorionic plate arteries. Placenta 36, 638-644. doi: 10.1016/j.placenta. 2015.03.007

Mondéjar-Parreño, G., Moral-Sanz, J., Barreira, B., De la Cruz, A., Gonzalez, T., Callejo, M., et al. (2019). Activation of Kv7 channels as a novel mechanism for NO/cGMP-induced pulmonary vasodilation. Br. J. Pharmacol. 176, 2131-2145. doi: 10.1111/bph.14662

Morales-Cano, D., Moreno, L., Barreira, B., Pandolfi, R., Chamorro, V., Jimenez, R., et al. (2015). Kv7 channels critically determine coronary artery reactivity: left-right differences and down-regulation by hyperglycaemia. Cardiovasc. Res. 106, 98-108. doi: 10.1093/cvr/cvv020

Mulvany, M. J., and Halpern, W. (1976). Mechanical properties of vascular smooth muscle cells in situ. Nature 260, 617-619. doi: 10.1038/260617a0 
Ng, F. L., Davis, A. J., Jepps, T. A., Harhun, M. I., Yeung, S. Y., Wan, A., et al. (2011). Expression and function of the $\mathrm{K}+$ channel KCNQ genes in human arteries. $\mathrm{Br}$. J. Pharmacol. 162, 42-53. doi: 10.1111/j.1476-5381.2010.01027.x

Ohya, S., Sergeant, G. P., Greenwood, I. A., and Horowitz, B. (2003). Molecular variants of KCNQ channels expressed in murine portal vein myocytes: a role in delayed rectifier current. Circ. Res. 92, 1016-1023. doi: 10.1161/01.RES. 0000070880.20955.F4

Oliveras, A., Roura-Ferrer, M., Solé, L., De La Cruz, A., Prieto, A., Etxebarria, A., et al. (2014). Functional assembly of Kv7.1/Kv7.5 channels with emerging properties on vascular muscle physiology. Arterioscler. Thromb. Vasc. Biol. 23, 1522-1530. doi: 10.1161/ATVBAHA.114.303801

Parsons, S. J. W., Hill, A., Waldron, G. J., Plane, T., and Garland, C. J. (1994). The relative importance of nitric oxide and nitric oxide-independent mechanisms in acetylcholine-evoked dilatation of the rat mesenteric bed. Br. J. Pharmacol. 113, 1275-1280. doi: 10.1111/j.1476-5381.1994.tb17 136. $\mathrm{x}$

Peredo, H. A., Feleder, E. C., and Adler-Graschinsky, E. (1997). Differential effects of acetylcholine and bradykinin on prostanoid release from the rat mesenteric bed: role of endothelium and of nitric oxide. Prostaglandins Leukot. Essent. Fatty Acids 56, 253-258. doi: 10.1016/S0952-3278(97)90567-6

Sandow, S. L., Goto, K., Rummery, N. M., and Hill, C. E. (2004). Developmental changes in myoendothelial gap junction mediated vasodilator activity in the rat saphenous artery. J. Physiol. 556(Pt 3), 875-886. doi: 10.1113/jphysiol.2003. 058669

Sandow, S. L., Haddock, R. E., Hill, C. E., Chadha, P. S., Kerr, P. M., Welsh, D. G., et al. (2009). What's where and why at a vascular myoendothelial microdomain signalling complex. Clin. Exp. Pharmacol. Physiol. 36, 67-76. doi: 10.1111/j. 1440-1681.2008.05076.x

Sandow, S. L., Neylon, C. B., Chen, M. X., and Garland, C. J. (2006). Spatial separation of endothelial small- and intermediate-conductance calciumactivated potassium channels $(\mathrm{KCa})$ and connexins: possible relationship to vasodilator function? J. Anat. 209, 689-698. doi: 10.1111/j.1469-7580.2006. 00647.x

Sandow, S. L., Senadheera, S., Bertrand, P. P., Murphy, T. V., and Tare, M. (2012). Myoendothelial contacts, gap junctions, and microdomains: anatomical links to function? Microcirculation 19, 403-415. doi: 10.1111/j.1549-8719.2011. 00146.x

Sandow, S. L., Tare, M., Coleman, H. A., Hill, C. E., and Parkington, H. C. (2002). Involvement of myoendothelial gap junctions in the actions of endotheliumderived hyperpolarizing factor. Circ. Res. 90, 1108-1113. doi: 10.1161/01.RES. 0000019756.88731 .83

Schenzer, A. (2005). Molecular Determinants of KCNQ (Kv7) K+ channel sensitivity to the anticonvulsant retigabine. J. Neurosci. 25, 5051-5060. doi: 10.1523/JNEUROSCI.0128-05.2005

Schnee, M. E., and Brown, B. S. (1998). Selectivity of linopirdine (DuP 996), a neurotransmitter release enhancer, in blocking voltage-dependent and calciumactivated potassium currents in hippocampal neurons. J. Pharmacol. Exp. Ther. 286, 709-717.

Senadheera, S., Kim, Y., Grayson, T. H., Toemoe, S., Kochukov, M. Y., Abramowitz, J., et al. (2012). Transient receptor potential canonical type 3 channels facilitate endothelium-derived hyperpolarization-mediated resistance artery vasodilator activity. Cardiovasc. Res. 95, 439-447. doi: 10.1093/cvr/ cvs208

Shimokawa, H., Yasutake, H., Fujii, K., Owada, M. K., Nakaike, R., Fukumoto, Y., et al. (1996). The importance of the hyperpolarizing mechanism increases as the vessel size decreases in endothelium-dependent relaxations in rat mesenteric circulation. J. Cardiovasc. Pharmacol. 28, 703-711. doi: 10.1097/00005344199611000-00014

Smith, P. D., Brett, S. E., Luykenaar, K. D., Sandow, S. L., Marrelli, S. P., Vigmond, E. J., et al. (2008). KIR channels function as electrical amplifiers in rat vascular smooth muscle. J. Physiol. 586, 1147-1160. doi: 10.1113/jphysiol.2007. 145474
Sonkusare, S. K., Dalsgaard, T., Bonev, A. D., and Nelson, M. T. (2016). Inward rectifier potassium (Kir2.1) channels as end-stage boosters of endotheliumdependent vasodilators. J. Physiol. 594, 3271-3285. doi: 10.1113/JP2 71652

Spoerri, E., Jentsch, J., and Glees, P. (1975). Apamin from bee venom. Effects of the neurotoxin on subcellular particles of neural cultures. FEBS Lett. 52, 143-147. doi: 10.1016/0014-5793(75)80006-8

Stott, J. B., Barrese, V., Jepps, T. A., Leighton, E. V., and Greenwood, I. A. (2015). Contribution of Kv7 channels to natriuretic peptide mediated vasodilation in normal and hypertensive rats. Hypertension 65, 676-682. doi: 10.1161/ HYPERTENSIONAHA.114.04373

Stott, J. B., Jepps, T. A., and Greenwood, I. A. (2014). $\mathrm{K}_{V} 7$ potassium channels: a new therapeutic target in smooth muscle disorders. Drug Discov. Today 19, 413-424. doi: 10.1016/j.drudis.2013.12.003

Tare, M., Coleman, H. A., and Parkington, H. C. (2002). Glycyrrhetinic derivatives inhibit hyperpolarization in endothelial cells of guinea pig and rat arteries. Am. J. Physiol. Heart Circ. Physiol. 282, H335-H341. doi: 10.1152/ajpheart.2002.282. 1.H335

Wang, H. R., Wu, M., Yu, H., Long, S., Stevens, A., Engers, D. W., et al. (2011). Selective inhibition of the Kir2 family of inward rectifier potassium channels by a small molecule probe: The discovery, SAR, and pharmacological characterization of ML133. ACS Chem. Biol. 6, 845-856. doi: 10.1021/ cb200146a

Wu, M., Wang, H., Yu, H., Makhina, E., Xu, J., Dawson, E. S., et al. (2010). “A potent and selective small molecule Kir2.1 inhibitor," in Probe Reports from the NIH Molecular Libraries Program, (Bethesda, MD: National Center for Biotechnology Information).

Wulff, H., Miller, M. J., Hänsel, W., Grissmer, S., Cahalan, M. D., and Chandy, K. G. (2000). Design of a potent and selective inhibitor of the intermediate- conductance Ca2+-activated $\mathrm{K}+$ channel, IKCa1: a potential immunosuppressant. Proc. Natl. Acad. Sci. U. S. A. 97, 8151-8156. doi: 10.1073/ pnas.97.14.8151

Yeung, S. Y. M., Pucovský, V., Moffatt, J. D., Saldanha, L., Schwake, M., Ohya, S., et al. (2007). Molecular expression and pharmacological identification of a role for Kv7 channels in murine vascular reactivity. Br. J. Pharmacol. 151, 758-770. doi: 10.1038/sj.bjp.0707284

Yu, H., Lin, Z., Xu, K., Huang, X., Long, S., Wu, M., et al. (2013). "Identification of a novel, small molecule activator of KCNQ1 channels," in Probe Reports from the NIH Molecular Libraries Program, (Bethesda, MD: National Center for Biotechnology Information).

Zechariah, A., Tran, C. H. T., Hald, B. O., Sandow, S. L., Sancho, M., Kim, M. S. M., et al. (2020). Intercellular conduction optimizes arterial network function and conserves blood flow homeostasis during cerebrovascular challenges. Arterioscler. Thromb. Vasc. Biol. 40, 733-750. doi: 10.1161/ATVBAHA.119. 313391

Zhong, X. Z., Harhun, M. I., Olesen, S. P., Ohya, S., Moffatt, J. D., Cole, W. C., et al. (2010). Participation of KCNQ (Kv7) potassium channels in myogenic control of cerebral arterial diameter. J. Physiol. 588(Pt 17), 3277-3293. doi: 10.1113/jphysiol.2010.192823

Conflict of Interest: The authors declare that the research was conducted in the absence of any commercial or financial relationships that could be construed as a potential conflict of interest.

Copyright (c) 2020 Baldwin, Sandow, Mondéjar-Parreño, Stott and Greenwood. This is an open-access article distributed under the terms of the Creative Commons Attribution License (CC BY). The use, distribution or reproduction in other forums is permitted, provided the original author(s) and the copyright owner(s) are credited and that the original publication in this journal is cited, in accordance with accepted academic practice. No use, distribution or reproduction is permitted which does not comply with these terms. 